\title{
Effects of Protein, Calcium, and pH on Gene Transcription, Cell-Envelope Peptidase Activity of Lactococcus lactis Strains, and the Formation of Bitter Peptides
}

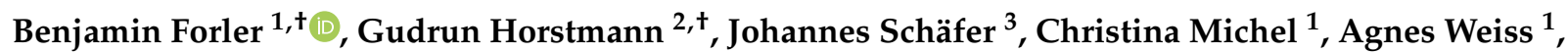 \\ Timo Stressler ${ }^{2}$, Lutz Fischer ${ }^{2}$, Jörg Hinrichs ${ }^{3}$ and Herbert Schmidt ${ }^{1, *(D)}$
}

1 Department of Food Microbiology and Hygiene, Institute of Food Science and Biotechnology, University of Hohenheim, Garbenstrasse 28, 70599 Stuttgart, Germany; benjamin.forler@uni-hohenheim.de (B.F.); christina.michel@uni-hohenheim.de (C.M.); agnes.weiss@uni-hohenheim.de (A.W.)

2 Department of Biotechnology and Enzyme Science, Institute of Food Science and Biotechnology, University of Hohenheim, Garbenstrasse 25, 70599 Stuttgart, Germany; gudrun.horstmann@uni-hohenheim.de (G.H.); timo.stressler@abenzymes.com (T.S.); Lutz.Fischer@uni-hohenheim.de (L.F.)

3 Department of Soft Matter Science and Dairy Technology, Institute of Food Science and Biotechnology, University of Hohenheim, Garbenstrasse 21, 70599 Stuttgart, Germany; J.Schaefer-3018@t-online.de (J.S.); j.hinrichs@uni-hohenheim.de (J.H.)

* Correspondence: herbert.schmidt@uni-hohenheim.de; Tel.: +49-711-459-22305

+ Both authors contributed equally to this work.

Citation: Forler, B.; Horstmann, G. Schäfer, J.; Michel, C.; Weiss, A.; Stressler, T.; Fischer, L.; Hinrichs, J.; Schmidt, H. Effects of Protein,

Calcium, and $\mathrm{pH}$ on Gene

Transcription, Cell-Envelope

Peptidase Activity of Lactococcus lactis Strains, and the Formation of Bitter Peptides. Foods 2021, 10, 1588. https://doi.org/10.3390/ foods10071588

Academic Editor: Vincenzo Cunsolo

Received: 1 June 2021

Accepted: 29 June 2021

Published: 8 July 2021

Publisher's Note: MDPI stays neutral with regard to jurisdictional claims in published maps and institutional affiliations.

Copyright: (C) 2021 by the authors. Licensee MDPI, Basel, Switzerland. This article is an open access article distributed under the terms and conditions of the Creative Commons Attribution (CC BY) license (https:// creativecommons.org/licenses/by/ $4.0 /$ )
Abstract: Calcium- and protein-rich fermented milk products, such as concentrated yoghurts and fresh cheeses, may contain undesired bitter peptides, which are generated by the proteolytic cleavage of casein. Up to now, it is not clear whether this process is caused by endogenous milk enzymes, such as plasmin and cathepsin D, or whether proteolytic enzymes from applied starter cultures, such as the lactococcal cell-envelope peptidase PrtP, are involved. A sensory analysis of fresh cheese products made from milk concentrates fermented with $\operatorname{prtP}$-negative and -positive Lactococcus lactis strains revealed bitterness in the products fermented with prtP-positive L. lactis strains. Two prtP-positive strains, LTH 7122 and LTH 7123, were selected to investigate the effect of increased calcium concentrations (additional $5 \mathrm{mM}$ and $50 \mathrm{mM} \mathrm{CaCl}_{2}$ ) at neutral ( $\mathrm{pH} \mathrm{6.6)} \mathrm{and} \mathrm{acidic} \mathrm{(} \mathrm{pH}$ 5.5) $\mathrm{pH}$-values on the transcription of the prtP gene and its corresponding PrtP peptidase activity in milk citrate broth (MCB). For both strains, it was shown that prtP transcription was upregulated only under slightly elevated calcium conditions $\left(5 \mathrm{mM} \mathrm{CaCl}_{2}\right)$ after $5 \mathrm{~h}$ of growth. In concordance with these findings, PrtP peptidase activity also increased. When higher concentrations of calcium were used (50 $\mathrm{mM})$, prtP expression of both strains decreased strongly by more than $50 \%$. Moreover, PrtP peptidase activity of strain LTH 7123 decreased by 15\%, but enzymatic activity of strain LTH 7122 increased slightly during growth under elevated calcium concentrations $(50 \mathrm{mM} \mathrm{CaCl}$ ). Fermentations of reconstituted casein medium with $3.4 \%(w / v)$ and $8.5 \%(w / v)$ protein and different calcium concentrations using strain LTH 7122 revealed no clear relationship between $p r t P$ transcription and calcium or protein concentration. However, an increase in PrtP peptidase activity under elevated protein and calcium conditions was observed. The activity increase was accompanied by increased levels of bitter peptides derived from different casein fractions. These findings could be a possible explanation for the bitterness in fermented milk concentrates that was detected by a trained bitter panel.

Keywords: concentrated fermented milk products; micro fresh cheese products; bitter peptides; transcriptional regulation; lactococcal cell-envelope peptidase PrtP activity

\section{Introduction}

The production of fermented milk products, such as curd cheese, strained (Greek-style) yogurt, or different types of fresh cheese, generates acid whey. Due to its high content of lactic acid, insoluble whey proteins, minerals such as calcium, enzymes, microorganisms 
and their metabolites, acid whey is difficult to process [1-5]. To cope with the increasing interest in fermented milk products containing a high protein content $(>8 \%)$, such as Skyr or strained yogurt, and to bypass issues regarding acid whey, fermentation of calcium-rich concentrated milk, yielding a precious neutral "ideal whey" or permeate instead, seems to be an interesting alternative. Unfortunately, formation of bitter off-flavors in the fermented products has been found $[5,6]$. Since approximately $70 \%$ of milk calcium (valid for a native milk pH of about 6.6 and $20^{\circ} \mathrm{C}$ ) [7] is bound to the casein micelles, it is concentrated along with it by using membranes like ultra- or microfiltration [8]. The elevated protein and calcium content of concentrated milk, when used for fermentation, may alter the proteolytic activities of either milk-endogenous peptidases or those produced by the bacterial starter cultures [6].

Effective growth of lactic acid bacteria (LAB) depends strongly on their proteolytic system, as they are auxotrophic for several amino acids [9-11]. For this reason, most LAB express a membrane-anchored endopeptidase PrtP (alternatively cell-envelope peptidase) with an extracellular proteolytic domain that is responsible for the initial breakdown of surrounding milk proteins into oligopeptides [12-14]. PrtP-derived peptides can be easily transported into the cell by the oligopeptide permease Opp, which transports oligopeptides in the size of 4-35 amino acid residues. At least two other oligopeptide transporters, the dipeptide transporter Dpp and the di-/tripeptide transporter DtpT, which mainly transport smaller peptides [11], are also involved. The intracellular peptides are then further degraded into amino acids by synergistic effects of certain endo- and exopeptidases $[10,15]$

The cell-wall bound PrtP of L. lactis strains is encoded by the prtP gene, which is located on large plasmids (up to $80 \mathrm{kbp}$, see Table S1) and expressed as an inactive proform of about $200 \mathrm{kDa}$. After translocation through the cytoplasmic membrane, PrtP is activated by its membrane-anchored maturation protein PrtM $[13,15-18]$. The external part of PrtP harbors at least three calcium binding sites that support the stability of the peptidase as well as the maintenance of correct folding if calcium ions are present [19-21]. A classification system for lactococcal PrtP peptidases was proposed by Exterkate et al. in 1993 [22], where PrtP peptidases of different L. lactis strains were classified into seven groups based on the specificity of the peptidases towards the $\alpha_{\mathrm{S} 1}$-casein fragment (1-23). An eighth group was introduced in 1998 by Broadbent et al. [23]. As the specificity of the PrtP peptidases in L. lactis is very diverse, cleavage of the milk caseins by PrtP can yield more than 100 different peptides, among them important aroma components as well as bitter-tasting peptides $[12,13,24-26]$. The contribution of the starter culture on the formation of bitter peptides during the fermentation of concentrated milk ( $>8 \%$ protein) to produce fresh cheese was investigated by Sebald et al. [6]. In total, seventeen key bitter peptides derived from all casein fractions were detected. Especially, the peptides MAPKHKEMPFPKYPVEPF (derived from $\beta$-casein) and ARHPHPHLSFM (derived from $\kappa$-casein) were found to be primary contributors for sensory bitterness in fresh cheese made from concentrated milk [6].

The aim of the current study was to investigate the effects of increased calcium and protein concentrations on the transcription of the lactococcal PrtP peptidase gene as well as on the peptidase activity. Therefore, a micro fresh cheese model $(\mu \mathrm{CoF})$ was used for the selection of bitterness-inducing L. lactis strains. These strains were used to investigate the influence of elevated calcium concentrations and a decreased $\mathrm{pH}$-value on prtP transcription and PrtP peptidase activity in a milk citrate broth (MCB), which is described to initiate proteolytic activity in Lacticaseibacillus casei [27]. Moreover, one prtPpositive L. lactis strain was selected for fermentation in reconstituted casein medium with different protein and calcium concentrations. The impact of prtP transcription and PrtP peptidase activity on the formation of the aforementioned bitter peptides was quantified. 


\section{Materials and Methods}

\subsection{Strains and Plasmids}

Bacterial strains and plasmids used in this study are listed in Table 1. L. lactis ssp. cremoris strain LTH 7122 and L. lactis ssp. lactis strain LTH 7123 were isolated from batch 3369251 of the starter culture F-DVS CC-06 (Christian Hansen Holding GmbH, Nienburg/Weser, Germany). L. lactis ssp. lactis strain LTH 7112 (syn. SL 124) and L. lactis ssp. cremoris strain LTH 7117 (syn. SC 134) were obtained from Sacco Srl, Cadorago, Italy. L. lactis strains were routinely grown in M17 broth over night and on M17 agar (both Merck KGaA, Darmstadt, Germany) for one to two days at $30{ }^{\circ} \mathrm{C}$. Overnight cultures were prepared by inoculating M17 broth with colonies of the respective strain and incubating them at $30^{\circ} \mathrm{C}$ without shaking under aerobic conditions.

Table 1. Strains and plasmids used in this study.

\begin{tabular}{|c|c|c|}
\hline Strain or Plasmid & $\begin{array}{l}\text { Subspecies and } \\
\text { Geno-/Phenotype }\end{array}$ & Reference or Source \\
\hline \multicolumn{3}{|l|}{ L. lactis } \\
\hline LTH 1657 & ssp. cremoris $\mathbf{T}$, prtP-positive & ATCC 19257 \\
\hline LTH 1418 & ssp. lactis $\mathbf{T}$, prtP-negative & ATCC 19435 \\
\hline & & Christian Hansen Holding \\
\hline LTH 7122 & ssp. cremoris, prtP-positive & $\begin{array}{l}\text { GmbH, Nienburg/Weser, } \\
\text { Germany, this study }\end{array}$ \\
\hline LTH 7123 & ssp. lactis, prtP-positive & $\begin{array}{l}\text { Christian Hansen Holding } \\
\text { GmbH, Nienburg/Weser, } \\
\text { Germany, this study }\end{array}$ \\
\hline LTH 7117 & ssp. cremoris, $p r t P$-negative & Sacco Srl, Cadorago, Italy \\
\hline LTH 7112 & ssp. lactis, prtP-negative & Sacco Srl, Cadorago, Italy \\
\hline \multicolumn{3}{|l|}{ E. coli } \\
\hline $\mathrm{DH} 5 \alpha$ & $\begin{array}{l}\text { tonA lacZ } \triangle \mathrm{M} 15 \text { endA1 recA1 thi-1 } \\
\text { supE44 phoA gyrA96 hsdR17 } \\
\Delta(\text { lacZYA-argF)U169 relA1 }\end{array}$ & Invitrogen, Carlsbad, CA, USA \\
\hline $\begin{array}{l}\mathrm{DH} 5 \alpha / \mathrm{pCM} 01 \\
\text { Plasmids }\end{array}$ & Donor for plasmid pCM01 & This study \\
\hline pGEM $^{\circledR}$-T Easy & Vector for cloning of PCR products & $\begin{array}{c}\text { Promega Corporation, Madison, } \\
\text { WI, USA }\end{array}$ \\
\hline pCM01 & $\begin{array}{l}163 \text { bp prtP PCR product, cloned } \\
\text { into pGEM }{ }^{\circledR} \text {-T Easy }\end{array}$ & This study \\
\hline
\end{tabular}

$\overline{\mathrm{T}}$ = type strain; ATCC = American Type Culture Collection (https://www.lgcstandards-atcc.org/en/Products/ Cells_and_Microorganisms/Bacteria.aspx, accessed on 31 May 2021).

Escherichia coli strains were routinely grown in Luria-Bertani (LB) broth [28]. Overnight cultures were prepared by inoculating LB broth with a single colony and incubating them at $37^{\circ} \mathrm{C}, 180 \mathrm{rpm}$, in a rotary incubator.

\subsection{Fermentation of Concentrated Milks}

\subsubsection{Experimental Setup for Fermentation}

In order to investigate the impact of the selected L. lactis strains on the fermentation characteristics and sensory properties of fresh cheese $(\mathrm{CoF})$ made from concentrated milks obtained by microfiltration, a so-called micro fresh cheese system ( $\mu$ FCS) was used. The $\mu F C S$, which was described previously by Schäfer et al. [29], is an experimental setup at laboratory scale for fermentation of (concentrated) milk combined with $\mathrm{pH}$ monitoring and logging. For fermentation experiments, micellar casein powder (MCC60), which was prepared according to Schäfer et al. [29], was used. The contents of protein, dry matter, lactose, and calcium were $57.06 \pm 0.12 \mathrm{~g} / 100 \mathrm{~g}, 96.05 \pm 0.12 \mathrm{~g} / 100 \mathrm{~g}, 29.96 \pm 0.85 \mathrm{~g} / 100 \mathrm{~g}$, and $19.82 \pm 0.33 \mathrm{~g} / \mathrm{kg}$, respectively. The MCC60 powder was reconstituted (protein concentration: $8.5 \%(w / w)$; calcium content: $2.98 \mathrm{~g} / \mathrm{kg}(74 \mathrm{mM}$; see Table 2$))$ with deionized water for $5 \mathrm{~min}$ at $50{ }^{\circ} \mathrm{C}$ and approx. $8.000 \mathrm{rpm}$ using a rotor-stator mixer (Ultra-Turrax T50, 
IKA-Werke GmbH \& Co. KG, Staufen, Germany). A batch-pasteurization $\left(72{ }^{\circ} \mathrm{C}\right.$ for $\left.15 \mathrm{~s}\right)$ of the concentrate was conducted by means of a water bath adjusted to $85^{\circ} \mathrm{C}$. Pasteurization was stopped by cooling in ice water, and the concentrates were stored at $6{ }^{\circ} \mathrm{C}$ until use. The concentrated milk was warmed up to the fermentation temperature of $22.5^{\circ} \mathrm{C}$ and transferred into sterilized plastic containers (volume $=400 \mathrm{~mL}$ ) under a laminar flow cabinet. Each concentrate-filled container was inoculated with approx. $4.5 \times 10^{9}$ colonyforming units (cfu) of each L. lactis strain. Containers were closed and sterilized $\mathrm{pH}$ probes (SE555X/2-NMSN; Knick Elektronische Messgeräte GmbH \& Co. KG, Berlin, Germany) were inserted.

Table 2. Chemical composition and fermentation characteristics of (reference) fermented-concentrated and concentratedfermented fresh cheeses manufactured by means of fermentation and without fermentation (control, direct acidified). Values represent the means and standard deviations $(i=2, n=2)$.

\begin{tabular}{|c|c|c|c|c|c|c|c|c|}
\hline $\begin{array}{l}\text { Fresh Cheese } \\
\text { Sample }\end{array}$ & Strain & prtP & $\begin{array}{c}\text { Protein } \\
(\%, w / w)\end{array}$ & $\underset{(g / k g)}{\text { Calcium }^{a}}$ & $\begin{array}{c}\text { Inital } \mathrm{pH} \\
(-)\end{array}$ & $\underset{(-)}{\text { Final } \mathrm{pH}}$ & $\begin{array}{l}\text { Fermentation } \\
\text { Time (h:min) }\end{array}$ & Texture $^{c}$ \\
\hline $\begin{array}{c}\text { FCo } \\
\text { (reference) }\end{array}$ & blend & $\begin{array}{l}\text { positive and } \\
\text { negative } \\
\text { strains }\end{array}$ & $8.8^{b}$ & $1.26^{\mathrm{b}}$ & n.i. & $4.5 \pm 0.1$ & n.i. & Paste-like \\
\hline $\begin{array}{l}\text { CoF (control, } \\
\text { directly } \\
\text { acidified) }\end{array}$ & n.d. & n.d. & 8.5 & 2.98 & $6.8 \pm 0.1$ & $4.7 \pm 0.1$ & n.d. & $\begin{array}{l}\text { Gel (Paste-like } \\
\text { after mechanical } \\
\text { treatment) }\end{array}$ \\
\hline $\mathrm{CoF}$ & $\begin{array}{l}\text { LTH } \\
7112\end{array}$ & negative & 8.5 & 2.98 & $6.6 \pm 0.1$ & $5.1 \pm 0.1$ & $65: 33 \pm 13: 15$ & $\begin{array}{l}\text { Liquid, gel } \\
\text { particles present }\end{array}$ \\
\hline $\mathrm{CoF}$ & $\begin{array}{l}\text { LTH } \\
7117\end{array}$ & negative & 8.5 & 2.98 & $6.7 \pm 0.1$ & $5.5 \pm 0.1$ & $50: 11 \pm 2: 59$ & $\begin{array}{l}\text { Liquid, gel } \\
\text { particles present }\end{array}$ \\
\hline $\mathrm{CoF}$ & $\begin{array}{l}\text { LTH } \\
7122\end{array}$ & positive & 8.5 & 2.98 & $6.7 \pm 0.1$ & $4.7 \pm 0.3$ & $41: 47 \pm 0: 1$ & $\begin{array}{l}\text { Liquid, gel } \\
\text { particles present }\end{array}$ \\
\hline $\mathrm{CoF}$ & $\begin{array}{l}\text { LTH } \\
7123\end{array}$ & positive & 8.5 & 2.98 & $6.7 \pm 0.1$ & $4.7 \pm 0.1$ & $27: 11 \pm 0: 11$ & $\begin{array}{l}\text { Gel (Paste-like } \\
\text { after mechanical } \\
\text { treatment) }\end{array}$ \\
\hline
\end{tabular}

${ }^{a}$ data was calculated by means of values from chapter $2.2 ;{ }^{b}$ according to manufacturer's specification; ${ }^{c}$ the texture of the fermented concentrates was evaluated prior to the mechanical treatment only via the naked eye. n.i.: not indicated by the manufacturer. n.d.: no data available. CoF: concentrated-fermented. FCo: fermented-concentrated.

The fermentation was conducted in a water bath (Kiss K 25; Peter Huber Kältemaschinenbau $\mathrm{GmbH}$, Offenburg, Germany) at a temperature of $22.5^{\circ} \mathrm{C}$, and acidification was continuously monitored until a $\mathrm{pH}$-value of 4.7 was achieved, or no change in $\mathrm{pH}$-values for $\geq 4 \mathrm{~h}$ was observed. Obtained fermented concentrated milks and fresh cheese samples, respectively, were cooled to $\leq 6{ }^{\circ} \mathrm{C}$ and stored until use. The data were converted (Advantech-ADAM-6217, Sphinx Computer Vertriebs-GmbH, Laudenbach, Germany; MemoRail A1401, Knick Elektronische Messgeräte GmbH \& Co. KG, Berlin, Germany), and $\mathrm{pH}$-values as a function of fermentation time were recorded by means of a software (DAQ Factory Express, AzeoTech Inc., Ashland, MA, USA). The initial and final pH-values as well as the fermentation time were evaluated.

Furthermore, a $\mathrm{CoF}$ fresh cheese control sample was manufactured without fermentation of the pasteurized concentrated milk, i.e., direct acidification, as described previously by Schäfer et al. [30]. An amount of about $400 \mathrm{~mL}$ concentrate contained in a double-walled beaker was cooled to $\leq 2{ }^{\circ} \mathrm{C}$ in a water bath. During continuous stirring, the $\mathrm{pH}$-value was adjusted to $\mathrm{pH} 4.7$ by dropwise addition of $1 \mathrm{M}$ citric acid (Carl Roth GmbH \& Co. KG, Karlsruhe, Germany). To ensure a steady final $\mathrm{pH}, 10$ min equilibration time were met and, if necessary, citric acid was added dropwise again. The acidified concentrated milk was filled into a sterilized plastic container (volume $=400 \mathrm{~mL}$ ), and gel formation was initiated by means of warming using a water bath $\left(15^{\circ} \mathrm{C}\right)$ for a holding time of $2 \mathrm{~h}$. The control CoF fresh cheese sample was cooled to $\leq 6{ }^{\circ} \mathrm{C}$ and stored until use. The manufacture of all $\mathrm{CoF}$ fresh cheeses was performed in duplicate.

As a reference fresh cheese sample, a commercially available fermented-concentrated (FCo) fresh cheese (Cremiger Quark mit frischem Joghurt, Berchtesgadener Land Chiemgau 
eG (D-BY 110 EG), Piding, Germany) was used containing $8.8 \mathrm{~g} / 100 \mathrm{~g}$ protein and $1.26 \mathrm{~g} / \mathrm{kg}$ calcium (31 mM) (Table 2).

\subsubsection{Sensory Evaluation of the Bitterness Level}

The level of bitterness of the fresh cheese samples was evaluated after one week of storage by a trained sensory panel. The panel consisted of 25 members (male/female/diverse; smoker/non-smoker; age: approx. 22 to 58 years), and they were trained to evaluate the level of bitterness using caffeine solutions of $0.05,0.1,0.15,0.175,0.2,0.25$, and $0.3 \mathrm{~g} / \mathrm{L}$, respectively, according to the standard DIN ISO 3972:2013-12 [31] of the German Institute for Standardization (DIN)/International Organization for Standardization (ISO). All panelists could identify a caffeine concentration of at least $0.25 \mathrm{~g} / \mathrm{L}$ as bitter, which fits the requirements recommended for a bitterness evaluation of food samples [31]. The training and evaluations were carried out at $22-25{ }^{\circ} \mathrm{C}$ in the Dr. Rainer-Wild sensory laboratory of the Institute of Food Science and Biotechnology, University of Hohenheim, Stuttgart, Germany, in separated booths.

In order to compare the fresh cheeses, they should have nearly the same appearance and consistency. Thus, prior to the sensorial evaluation, all fresh cheeses were mechanically treated with a hand blender (ESGE-Zauberstab M180, ESGE AG, Mettlen, Switzerland) at level two $(n=17,000 \mathrm{rpm})$ for 10 to $180 \mathrm{~s}$ until visibly smooth and homogenous masses, i.e., liquid to paste-like microgel suspensions, were obtained. The challenge was that some samples were liquid-like and contained gel particles; thus, a very short blending time of approximately $10 \mathrm{~s}$ had to be applied, and other samples appeared to be too thin. In order to evaluate the bitterness level of the fresh cheese samples, a polarized sensory positioning was carried out [32,33].

Depending on each trial, the number of panelists varied between 12 and 13. At each session, prior to the sensorial evaluation, two samples were served as reference for the panelists: (1) a commercially available FCo fresh cheese (Cremiger Quark mit frischem Joghurt, Berchtesgadener Land Chiemgau eG (D-BY 110 EG), Piding, Germany) and (2) a CoF fresh cheese which was manufactured from the reconstituted MCC60 powder and was fermented with the strain LTH 7122 at $22.5^{\circ} \mathrm{C}$. As this fresh cheese was ranked as very bitter by the sensorial panel, this fresh cheese was used as a bitter reference.

The reference samples gave values of 0 (commercial FCo fresh cheese) and 4 (CoF fresh cheese fermented with LTH 7122) on a structured linear scale of $5 \mathrm{~cm}$ total length ranging from 0 to 5 (0: not bitter, 1: very slightly bitter, 2: slightly bitter, 3: bitter, 4 : very bitter, 5: extremely bitter).

The FCo fresh cheese product was chosen as a reference based on results of an inhouse sensorial evaluation indicating that the bitterness level was $\leq 2$ (slightly bitter) during 5 weeks of storage at approx. $6^{\circ} \mathrm{C}$, as described by Schäfer et al. [5].

Samples (approx. 20-30 g; temperature $=$ approx. $10^{\circ} \mathrm{C}$ ) of each fresh cheese were served in plastic containers labeled with randomized 3-digit numbers. To neutralize any carry-over taste during the sensorial evaluation, tap water and matzo bread (Pico Food $\mathrm{GmbH}$, Tamm, Germany) were served. As proposed by Sebald et al. [6], each panelist wore a nose-clip (Vitalograph $\mathrm{GmbH}$, Hamburg, Germany) to prevent cross-modal interactions with other odorants during sample evaluation using the scale as mentioned above and at individual speed.

\subsection{Isolation of L. lactis Plasmid DNA}

Plasmid DNA was isolated according to the protocol of Anderson and McKay [34] with the following modifications: after the addition of lysozyme $(10 \mathrm{mg} / \mathrm{mL}$, SERVA Electrophoresis GmbH, Heidelberg, Germany), $20 \mu \mathrm{L}$ RNase A (100 mg/mL, Qiagen $\mathrm{GmbH}$, Hilden, Germany) was added to the reaction mixes, which were incubated at $37^{\circ} \mathrm{C}$ for $60 \mathrm{~min}$. Phenol, which was saturated with TE-buffer and chloroform-isoamyl alcohol (both Carl Roth GmbH \& Co. KG, Karlsruhe, Germany), was used for the protocol. Purified 
plasmid DNA was dissolved in $30 \mu \mathrm{L}$ of TE-buffer and analyzed by electrophoresis on $0.8 \%$ $(w / v)$ agarose gels.

\subsection{PCR Analysis of prtP}

The presence of prtP was analyzed by amplifying a conserved region of 163 bp by PCR with the primers prtP_for (5'-CGC TTA GCC GCA TGT CTT TA-3') and prtP_rev (5'-ACA GTC ACA TTG GCG AAA GT- $3^{\prime}$ ). The PCR reaction mix consisted of $2.5 \mu \mathrm{L}$ ThermoPol ${ }^{\circledR}$ Buffer, $0.5 \mu \mathrm{L}$ deoxynucleoside triphosphate (dNTP) mix (10 mM each) and $0.125 \mu \mathrm{L}$ Taq DNA Polymerase $(5,000 \mathrm{U} / \mathrm{mL}$ ) (all New England Biolabs Inc., Ipswich, MA, USA), $0.5 \mu \mathrm{L}$ of each primer $(10 \mathrm{pmol} / \mu \mathrm{L}$, Eurofins Genomics $\mathrm{GmbH}$, Ebersberg, Germany), and $50 \mathrm{ng}$ of plasmid DNA as template. Plasmid DNA of strains LTH 1657 and LTH 1418 was used as prtP-positive and prtP-negative controls, respectively. A notemplate control (NTC) was included using sterile ultrapure water $\left(\mathrm{GIBCO}^{\mathrm{TM}}\right.$, Thermo Fisher Scientific Inc., Waltham, MA, USA) instead of template DNA. The volume was adjusted to $25 \mu \mathrm{L}$ with sterile ultrapure water $\left(\mathrm{GIBCO}^{\mathrm{TM}}\right.$, Thermo Fisher Scientific Inc., Waltham, MA, USA). The PCR reaction was conducted in a T1 thermocycler (Biometra $\mathrm{GmbH}$, Göttingen, Germany) with the following PCR conditions: initial denaturation, $95^{\circ} \mathrm{C}, 5 \mathrm{~min}$; 30 cycles of denaturation, $95^{\circ} \mathrm{C}, 0.5 \mathrm{~min}$, annealing, $51{ }^{\circ} \mathrm{C}, 0.5 \mathrm{~min}$, and elongation, $68^{\circ} \mathrm{C}, 0.5 \mathrm{~min}$; and a final elongation at $68^{\circ} \mathrm{C}, 5 \mathrm{~min}$. The primer pair was constructed with the software Primer3web (version 4.1.0; http:/ / primer3.ut.ee, accessed on 1 February 2018) using a conserved region of the prtP gene. This conserved region was identified by aligning known prtP sequences of different strains of L. lactis (Table S1) available at the National Center for Biology Information (NCBI).

2.5. Construction of a Plasmid Standard for the Absolute Quantification of prtP Gene Expression in a Quantitative Real-Time RT PCR ( $P$ PCR) Transcriptional Assay

For preparation of a plasmid standard for the absolute quantification of $p r t P$ transcription, the pGEM $^{\circledR}$-T Easy Vector System (Promega Corporation, Madison, WI, USA) was used. Therefore, the prtP PCR product of strain LTH 1657 (see Section 2.4) was purified with a QIAquick ${ }^{\circledR}$ PCR Purification Kit (Qiagen GmbH, Hilden, Germany) following the corresponding purification protocol. The purified PCR products were cloned into plasmid pGEM $^{\circledR}$-T Easy following the pGEM $^{\circledR}$-T and pGEM $^{\circledR}$-T Easy Vector Systems technical manual (revised 12/18, TM042). Fifty nanogram of plasmid DNA and a three-fold molar excess of the PCR product was chosen for a ligation reaction, which was incubated at $4{ }^{\circ} \mathrm{C}$ overnight. Preparation of chemically competent $E$. coli $\mathrm{DH} 5 \alpha$ cells and transformation procedures were carried out according to standard procedures [28]. Selection of transformants was carried out by blue-white screening on LB agar containing $100 \mu \mathrm{g} / \mathrm{mL}$ ampicillin, $0.5 \mathrm{mM}$ isopropyl $\beta$-D-thiogalactopyranoside (IPTG), and $80 \mu \mathrm{g} / \mathrm{mL}$ 5-bromo-4-chloro3-indoxyl- $\beta$-D-galactoside (X-Gal) (Carl Roth GmbH \& Co. KG, Karlsruhe, Germany), according to the pGEM $^{\circledR}$-T and pGEM $^{\circledR}$-T Easy Vector Systems technical manual. Positive transformants were chosen for the isolation of plasmid DNA with a QIAprep Spin Miniprep Kit (Qiagen GmbH, Hilden, Germany), according to the handbook (July 2006). The resulting plasmid was analyzed by gel electrophoresis and designated pCM01.

\subsection{Analysis of Lactococcal prtP Gene Expression during Casein Metabolism}

2.6.1. Preparation of Milk Citrate Broth, Calcium Solutions, and Reconstituted Casein Medium for Cultivation Experiments

For the preparation of $1 \mathrm{~L} \mathrm{MCB}, 4.4 \mathrm{~g}$ skim milk powder (Oxoid Ltd., Basingstoke, UK) was mixed with deionized water and adjusted to $500 \mathrm{~mL}$ and $\mathrm{pH}$ 7.2. Additionally, $5 \mathrm{~g}$ glucose (Merck KGaA, Darmstadt, Germany), $8 \mathrm{~g}$ trisodium citrate dihydrate (Carl Roth GmbH \& Co. KG, Karlsruhe, Germany), and $1 \mathrm{~g}$ yeast extract (Bacto ${ }^{\mathrm{TM}}$, Fisher Scientific $\mathrm{GmbH}$, Schwerte, Germany) were dissolved in deionized water and adjusted to $500 \mathrm{~mL}$ and $\mathrm{pH}$ 7.2. Both components were autoclaved separately, and the solutions were mixed under sterile conditions after cooling to $50{ }^{\circ} \mathrm{C}$ and stored at $4{ }^{\circ} \mathrm{C}$. The final $\mathrm{pH}$ of the 
autoclaved medium was 6.6. This medium is designated in the following as basic MCB ( $\mathrm{pH}$ 6.6).

In order to adjust the calcium content of the broth into the range of the CoF fresh cheese evaluated as bitter, sterile $0.5 \mathrm{M}$ and $5 \mathrm{M}$ calcium chloride stock solutions were used.

For cultivation in reconstituted casein medium with a modified calcium and protein content, the casein powders control MCC85 (protein content: $82.8 \pm 1.89 \%(w / w)$; calcium content: $27.17 \pm 0.01 \mathrm{~g} / \mathrm{kg}$ ) and calcium-reduced MCC85 (protein content: $85.23 \pm 1.03 \%$ $(w / w)$; calcium content: $15.25 \pm 0.21 \mathrm{~g} / \mathrm{kg}$ ) [29] were used. In this work, the powder control MCC85 was designated as SdCa-mCN (slightly calcium-depleted micellar casein), and powder calcium-reduced MCC85 was designated as HdCa-mCN (highly calcium-depleted micellar casein). The powder HdCa-mCN is calcium-reduced by approx. $45.1 \%$ compared to casein powder SdCa-mCN.

To get close to protein concentrations present in milk, the powders were reconstituted to a protein concentration of $3.4 \%(w / v)$, as described below. The respective calcium concentrations were $28 \mathrm{mM}$ for SdCa-mCN $(3.4 \%$ protein $(w / v))$ and $15 \mathrm{mM}$ for HdCa$\mathrm{mCN}(3.4 \%$ protein $(w / v))$. A high protein fermentation was conducted at a protein concentration of $8.5 \%(w / v)$, resulting in calcium concentrations of $70 \mathrm{mM}$ for SdCa-mCN $(8.5 \%$ protein $(w / v))$ and $38 \mathrm{mM}$ for HdCa-mCN $(8.5 \%$ protein $(w / v))$. Prior to fermentation, the solid casein powders were reconstituted in distilled and autoclaved water at $4{ }^{\circ} \mathrm{C}$ for 3-4 h, followed by a sterilization treatment at $95{ }^{\circ} \mathrm{C}$ for $30 \mathrm{~min}$ in a water bath. The sufficiency of the sterilization process was examined by use of plate count agar $(0.5 \%(w / v)$ peptone, $0.25 \%(w / v)$ yeast extract, $0.1 \%(w / v)$ glucose, $1.6 \%(w / v)$ agar, $\mathrm{pH} 7)$. After sterilization, the reconstituted casein medium was stirred slowly over night at $4{ }^{\circ} \mathrm{C}$ and then used for the fermentation experiments on the next day.

2.6.2. Cultivation of L. lactis Strains in Milk Citrate Broth and Reconstituted Casein Medium with Different Calcium and Protein Concentrations

Precultures in M17 broth were grown overnight (see Section 2.1) and the cells were harvested by centrifugation at $4255 \times g$, resuspended in $0.1 \mathrm{M}$ sodium phosphate buffer $\mathrm{pH} 7.2$, and the optical density at $600 \mathrm{~nm}\left(\mathrm{OD}_{600}\right)$ was determined with a $\mathrm{DU}^{\circledR} 730 \mathrm{UV} / \mathrm{Vis}$ Scanning Spectrophotometer (Beckman Coulter Inc., Brea, CA, USA). With this suspension, basic MCB or reconstituted casein medium (SdCa-/HdCa-mCN, each with $3.4 \%(w / v)$ and $8.5 \%(w / v)$ protein concentration) were inoculated to an $\mathrm{OD}_{600}$ of 0.1 . In the experimental approaches with basic MCB and high calcium concentrations (in the range of the CoF fresh cheeses), $10 \mu \mathrm{L}$ of the $0.5 \mathrm{M}$ calcium chloride solution $/ \mathrm{mL}$ was added to basic MCB (for additional $5 \mathrm{mM}$ calcium chloride) and $10 \mu \mathrm{L}$ of the $5 \mathrm{M}$ calcium chloride solution/mL (for additional $50 \mathrm{mM}$ calcium chloride) before addition of the cells.

After addition of $50 \mathrm{mM}$ calcium chloride to basic $\mathrm{MCB}$, the $\mathrm{pH}$-value dropped from 6.6 to 5.5. In the approaches with $\mathrm{MCB}(\mathrm{pH} 5.5), 3.4 \mu \mathrm{L} 4 \mathrm{~N} \mathrm{HCl} / \mathrm{mL}$ was added before addition of the cells to adjust the $\mathrm{pH}$-value to 5.5 .

The cultures were then incubated under aerobic conditions at $30{ }^{\circ} \mathrm{C}$ without shaking for $24 \mathrm{~h}$, and samples were taken hourly for serial dilution and were spread-plated in duplicate on M17 agar. The viable counts were determined after incubation at $30{ }^{\circ} \mathrm{C}$ for 24-48 h.

For RNA extraction, samples containing approx. $2 \times 10^{8} \mathrm{cfu}$ were taken in duplicate at the respective time points and treated with RNAprotect ${ }^{\circledR}$ Bacteria Reagent (Qiagen $\mathrm{GmbH}$, Hilden, Germany), according to the corresponding Handbook (January 2015) with the following modifications: centrifugation was performed at $4255 \times g$ and samples were stored at $-70{ }^{\circ} \mathrm{C}$ until further processing.

\subsubsection{Sample Preparation for prtP Transcriptional Analysis}

For RNA extraction, the samples (see Section 2.6.2) were thawed at room temperature and the RNA was isolated with the RNeasy ${ }^{\circledR}$ Mini Kit (Qiagen GmbH, Hilden, Germany) following protocols 4 and 7 of the RNAprotect ${ }^{\circledR}$ Bacteria Reagent Handbook with minor modifications. The samples were incubated at $37^{\circ} \mathrm{C}$ with $750 \mathrm{rpm}$ for $30 \mathrm{~min}$ on a ther- 
momixer (protocol 4). The RNA was eluted (protocol 7) with $50 \mu \mathrm{L}$ RNase-free water preheated to $37^{\circ} \mathrm{C}$ and kept on ice for further processing or stored at $-70{ }^{\circ} \mathrm{C}$. Residual DNA within the RNA preparations was degraded with the Turbo DNA-free ${ }^{\mathrm{TM}}$ Kit (Thermo Fisher Scientific Inc., Waltham, MA, USA) following the routine treatment protocol described in the TURBO DNA-free ${ }^{\mathrm{TM}}$ Kit User Guide (TURBO ${ }^{\mathrm{TM}}$ DNase Treatment and Removal Reagents, Revision G). The RNA integrity was examined by formaldehyde-based denaturing agarose gel electrophoresis. A total of $300 \mathrm{ng}$ of RNA were reverse transcribed into cDNA with the iScript ${ }^{\mathrm{TM}}$ Select cDNA Synthesis Kit (Bio-Rad Laboratories Inc., Hercules, CA, USA) following the instructions (10001023 Rev B) for the use of random primers. An additional approach with a no-reverse transcriptase control (-RT) was performed for each sample to detect residual DNA.

2.6.4. Generation of Standard Curves for the Absolute Quantification of prtP Expression in the qPCR Transcriptional Assay

Plasmid pCM01 was serially diluted with sterile ultrapure water $\left(\mathrm{GIBCO}^{\mathrm{TM}}\right.$, Thermo Fisher Scientific Inc., Waltham, MA, USA) to obtain $6.0 \times 10^{2}$ to $6.0 \times 10^{7}$ copies $/ \mu \mathrm{L}$ according to the technical manual "Creating Standard Curves with Genomic DNA or Plasmid DNA Templates for Use in Quantitative PCR" (Applied Biosystems, Waltham, MA, USA).

One microliter of each of pCM01 dilutions as well as $50 \mathrm{ng}$ plasmid template DNA of the L. lactis type strain LTH 1657 were used in the respective prtP-qPCR assay (see Section 2.6.5) in order to confirm that the gene copy numbers were covered by the dynamic range of the plasmid standard curves. In the qPCR assays, the standard curves were automatically created with the threshold cycle values $\left(C_{t}\right.$ values $)$ of the plasmid dilution series and the corresponding decadic logarithms of the starting quantity (either concentration or gene copy number) by the qPCR software (see Section 2.6.5). Three biological replicates with three technical replicates each were performed for proving the reproducibility of the standard plasmid curve, which all met the MIQE criteria [35].

\subsubsection{Establishment of a Real-Time PCR Assay for Absolute Quantification of prtP Transcription}

For the qPCR assays, an $\mathrm{iQ}^{\mathrm{TM}} 5$ Multicolor Real-Time PCR Detection System with the corresponding software (Bio-Rad Laboratories Inc., Hercules, CA, USA) was used. PCR reactions with the prtP primer pair (see Section 2.4) were analyzed in gradient-PCR followed by melting curve analysis (Table 3) in order to prove the specificity of the PCR reaction and to determine the respective annealing temperatures. For these analyses, the SsoAdvanced Universal SYBR Green Supermix (Bio-Rad Laboratories Inc., Hercules, CA, USA) was used together with the primers $(0.8 \mu \mathrm{L})$ and template DNA of the strain LTH 1657 (50 ng plasmid DNA) in a $20 \mu \mathrm{L}$ reaction. The qPCR was set to the following conditions: initial denaturation, $95^{\circ} \mathrm{C}, 5 \mathrm{~min}$, and 40 cycles of denaturation $\left(95^{\circ} \mathrm{C}, 0.5 \mathrm{~min}\right)$, annealing $\left(49.8^{\circ} \mathrm{C}, 0.5 \mathrm{~min}\right)$, and elongation $\left(68^{\circ} \mathrm{C}, 0.5 \mathrm{~min}\right.$; collection of optical data for gene expression analysis).

Table 3. Cycling programs of the gradient-PCR and melt curve analysis for the prtPqPCR establishment.

\begin{tabular}{cccc}
\hline Reaction Step & Temperature $\left({ }^{\circ} \mathbf{C}\right)$ & Time (s) & Cycles \\
\hline Initial denaturation & 95 & 300 & 1 \\
Denaturation & 95 & 30 & \\
Annealing & $59.0,58.5,57.3,55.4,52.9,51.1,49.8,49.0$ & 30 & 40 \\
Elongation * & 68 & 30 & \\
Denaturation & 95 & 60 & 1 \\
Renaturation & 25 & 60 & 1 \\
Denaturation ** & $25 \rightarrow 95$ (increase 0.5 per cycle) & 10 & 141
\end{tabular}

* Collection of optical data for the optimization of the annealing temperature. ${ }^{* *}$ Collection of optical data for the melt curve analysis. 


\subsection{Determination of PrtP Peptidase Activity}

The determination of PrtP activity was conducted as described by Hebert et al. [36]. Samples $(5 \mathrm{~mL})$ were taken and harvested by centrifugation $\left(4255 \times g, 4{ }^{\circ} \mathrm{C}, 10 \mathrm{~min}\right)$. Cells were washed with $0.9 \%(w / v)$ sodium chloride solution containing $10 \mathrm{mM}$ of calcium chloride to avoid detachment of PrtP from the cell surface [37]. Subsequently, the washed cells were suspended in $50 \mathrm{mM}$ sodium phosphate buffer ( $\mathrm{pH}$ 7.0) and applied in the peptidase activity assay. The PrtP activity was determined by use of the synthetic substrate Suc-Ala-Ala-Pro-Phe- $p$ NA (Bachem Holding AG, Bubendorf, Switzerland), which was dissolved in dimethylsulfoxide $(12 \mathrm{mg} / \mathrm{mL})$. The assay was conducted at a temperature of $30^{\circ} \mathrm{C}$ in a thermoshaker. A volume of $30 \mu \mathrm{L}$ of cell suspension was given to $200 \mu \mathrm{L}$ of sodium phosphate buffer ( $\mathrm{pH} 7$ ), $100 \mu \mathrm{L}$ of $5 \mathrm{M}$ sodium chloride, and $20 \mu \mathrm{L}$ of substrate solution. The substrate hydrolysis was stopped by addition of $100 \mu \mathrm{L}$ of $80 \%(v / v)$ acetic acid. The assay's incubation time was chosen with respect to the linear range of product formation as well as the assay's limit of detection (data not shown). Precipitated protein was removed via centrifugation $\left(17,950 \times g, 4{ }^{\circ} \mathrm{C}, 10 \mathrm{~min}\right)$, and $200 \mu \mathrm{L}$ of the supernatant was transferred into a 96-well plate for measuring the absorption at $405 \mathrm{~nm}$. One katal of PrtP peptidase activity was defined as the amount of PrtP that released $1 \mathrm{~mol}$ of $p \mathrm{NA}$ per second. Additionally, PrtP activity was standardized to its corresponding cfu (see Section 2.6.2).

\subsection{Quantification of Key Bitter Peptides}

Certain key bitter peptides [6] were quantified within the fermentations of reconstituted casein medium. The cultivations in SdCa-mCN and $\mathrm{HdCa}-\mathrm{mCN}$ medium $(3.4 \%$ and $8.5 \%(w / v)$ protein content) were done in triplicates, and samples were taken after 5 and $24 \mathrm{~h}$ from every cultivation. The peptides were extracted as described by Sebald et al. [6]. Therefore, $1 \pm 0.01 \mathrm{~g}$ of sample was extracted twice with $5 \mathrm{~mL}$ of $0.1 \%(v / v)$ formic acid by use of $3 \pm 0.1 \mathrm{~g}$ of glass beads $(\varnothing 3 \mathrm{~mm}$ ). The internal standard angiotensin I (final concentration: $1 \mu \mathrm{g} / \mathrm{mL}$ ) was given to the sample. After $3 \times 20 \mathrm{~s}$ of mixing on a vortex, the sample was centrifuged $\left(12,857 \times g, 4{ }^{\circ} \mathrm{C}, 10 \mathrm{~min}\right)$. The supernatant was adjusted to $10 \mathrm{~mL}$ in a measuring cylinder, sterile-filtered, and stored at $-20^{\circ} \mathrm{C}$ until further use. The concentration of bitter peptides was analyzed according to Sebald et al. [6] via mass-spectrometry by the Core Facility of the University of Hohenheim. The same peptides (peptides\&elephants, Hennigsdorf, Germany) as published by Sebald et al. [6] were used for the calibration and quantification of the peptides within the fresh cheese samples. The determined peptide concentrations were used to calculate the dose-over-threshold-factor (DoT-factor) for every peptide. For that, the bitter taste thresholds published by Sebald et al. [6] of the peptides were used. On the basis of the DoT-factor, the influence of a peptide on the bitter taste reception can be estimated. At a DoT-factor of $>1.0$, a peptide can be assumed as being involved in the reception of bitterness in a product. An additive contribution can be performed by subthreshold peptides with DoT-factors of $0.1 \leq$ DoT $\leq 1.0[6]$.

\subsection{Statistical Analysis}

Of each data set, the means of three biological replicates were used for statistical analysis (of the data set HdCa-mCN 3.4\% (w/v) for prtP transcriptional analysis, only two biological replicates could be used for analysis). Data sets of the different cultivation experiments were analyzed on normal distribution with the Anderson-Darling test. MCB data sets were compared to the reference (basic MCB) using an unpaired t-test. Fermentations in reconstituted casein medium were compared using analysis of variance (ANOVA). The variance homogeneity was identified using Brown-Forsythe test. If requirements were given, one-way ANOVA was performed using a post hoc Fisher's least significant difference (LSD) test $(\alpha=0.05)$. Statistical analysis was performed with the software OriginPro (version 2020, OriginLab Corporation, Northampton, MA, USA). Significant differences concerning the level of bitterness of the fresh cheeses were identified by conducting an 
ANOVA. If significant, a subsequent Fisher's LSD test $(\alpha=0.05)$ was applied. The software XLSTAT 2015 (version 2015.4.01.20575, Addinsoft, New York, NY, USA) was used.

\section{Results}

\subsection{Fermentation of Concentrated Milks for the Production of CoF Fresh Cheese Samples and Sensory Evaluation}

In order to produce fresh cheese $(\mathrm{CoF})$ samples with $\operatorname{prtP}$-positive and $p r t P$-negative L. lactis strains for sensory evaluation, reconstituted casein medium with initial $\mathrm{pH}$-values in a range of 6.6 to 6.8 were fermented until $\mathrm{pH}$-values of 4.7 to 5.5 were reached (Table 2). The use of the prtP-negative strains LTH 7117 and LTH 7112 resulted in prolonged fermentation times of approx. $50 \mathrm{~h}$ and $66 \mathrm{~h}$, respectively, as compared to fermentation with the prtP-positive strains LTH 7122 and LTH 7123 of approximately $27 \mathrm{~h}$ and $42 \mathrm{~h}$, respectively, to achieve the desired $\mathrm{pH}$-values under the same fermentation/growth conditions. Furthermore, $p r t P$-negative strains did not acidify the concentrated milks to $\mathrm{pH}$-values $\leq 5.1$. Consequently, no homogenous gel formation was observed by visual inspection (Figure S1). Whereas the CoF fresh cheese obtained with LTH 7123 with a pH of 4.7 showed a homogenous gel, the CoF fresh cheese with LTH 7122 with same final $\mathrm{pH}$ showed a liquid-like (microgel) suspension with gel-particles contained therein.

Sensory evaluation indicated that $\mathrm{CoF}$ fresh cheese samples prepared with the prtPnegative strains LTH 7117 and LTH 7112 were perceived with low bitterness levels of 1.7 and 2.8 , respectively, whereas the $\mathrm{CoF}$ fresh cheeses produced with prtP-positive strains LTH 7123 and LTH 7122 showed significantly higher bitterness levels of 3.9 and 4.1, respectively (Figure 1). CoF fresh cheeses obtained with the prtP-negative strains LTH 7117 and 7112 were perceived with higher bitterness levels than the commercial reference FCo fresh cheese with a bitterness level of 0.5 .

In conclusion, sensory evaluation of fermented CoF fresh cheese samples using prtPnegative and $p r t P$-positive strains revealed significantly higher bitterness levels than the non-fermented, directly acidified, CoF control sample (Figure 1).

The CoF-fresh-cheese sample fermented with strain LTH 7117 was also judged as slightly bitter. However, a significant difference in bitterness between the control CoF fresh cheese and the reference FCo fresh cheese was not noticed. Since the L. lactis strains LTH 7122 and LTH 7123 obviously were involved in the development of bitterness in the CoF fresh cheese, these strains were further investigated with molecular methods in terms of prtP transcription and PrtP activity.

\subsection{Growth of L. lactis Strains LTH 7122 and LTH 7123 in Basic MCB and Quantification of prtP Transcription}

In order to set up a system for quantitative analysis of $p r t P$ transcription under model conditions, basic MCB was used, which was previously described to initiate proteolytic activity in Lacticaseibacillus casei [27]. Initially, growth curves were generated with strains LTH 7122 and LTH 7123 in basic MCB (Figure 2, white squares) to evaluate the optimal conditions for qPCR. The cultures were started with a high inoculum of approx. $10^{8} \mathrm{cfu} / \mathrm{mL}$ to obtain sufficient RNA concentrations for qPCR analysis. Both strains showed similar growth characteristics in basic MCB and multiplied by approximately $1 \log$ (Figure 2A,B, white squares). Only slight differences in viable counts were found. The prtP transcription levels (Figure $3 \mathrm{~A}, \mathrm{~B}$ ) were highest after $3 \mathrm{~h}$ of growth with $2.2 \times 10^{5}$ copies/ng cDNA for LTH 7122 and $1.2 \times 10^{5}$ copies/ng cDNA for LTH 7123, demonstrating slight differences between the strains. Afterwards, a continuous decrease in transcription levels (copies/ng cDNA) was observed with increasing cultivation time. Thus, prtP gene expression levels of both strains were highest in the early growth phase; therefore, $3 \mathrm{~h}$ and $5 \mathrm{~h}$ appeared as the most promising time points for subsequent analysis of the effects of different calcium concentrations and a low $\mathrm{pH}$-value on $\mathrm{prtP}$ gene transcription. 


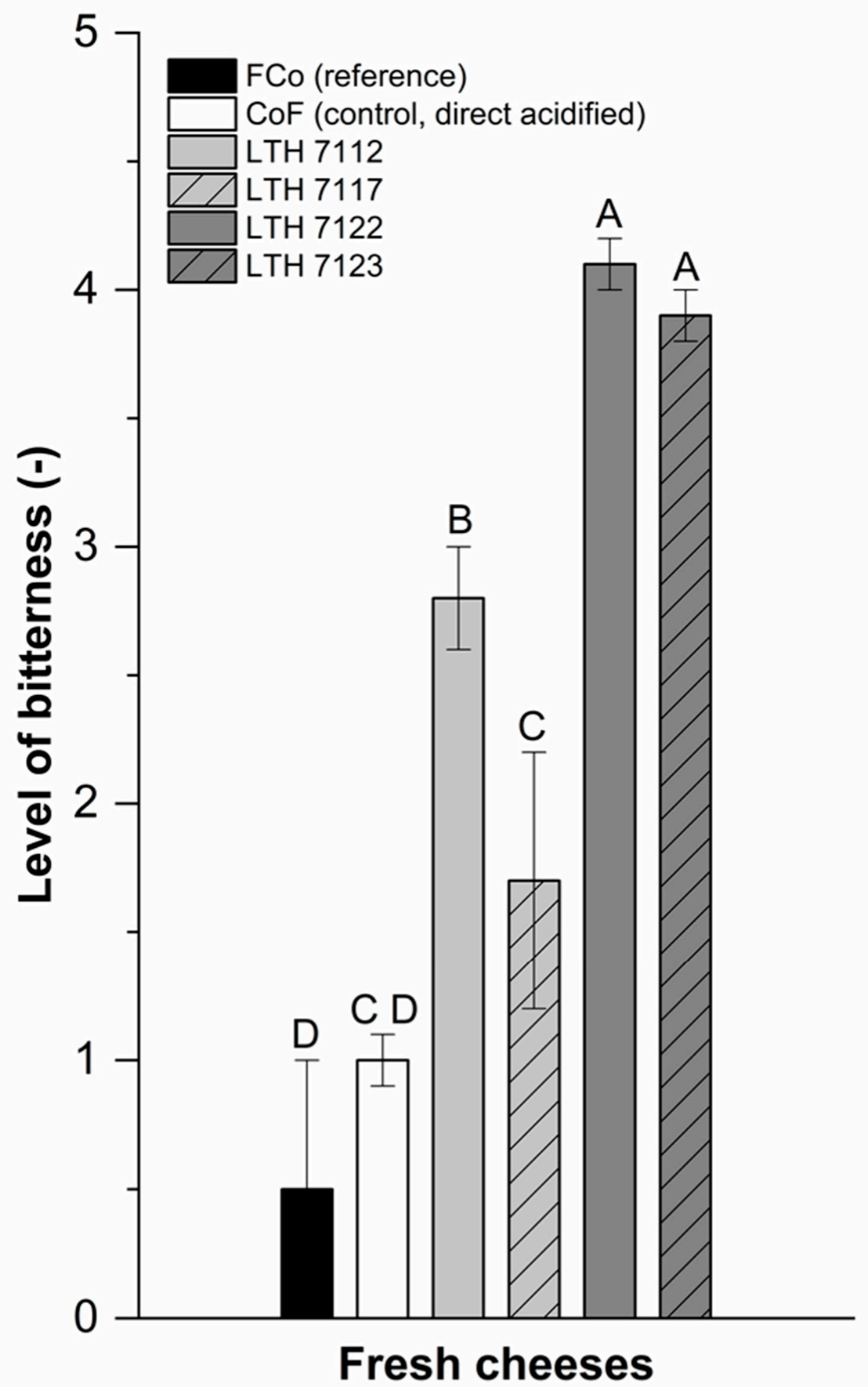

Figure 1. Level of bitterness of fermented-concentrated fresh cheese (FCo, black bar) used as a reference and concentrated-fermented $(\mathrm{CoF})$ fresh cheeses manufactured by fermentation with $L$. lactis strains LTH 7112 (prtP-negative), LTH 7117 (prtP-negative), LTH 7122 (prtP-positive), LTH 7123 (prtP-positive), and without fermentation by direct acidification ( $\mathrm{CoF}$, control). 0 : not bitter, 1: very slightly bitter, 2: slightly bitter, 3: bitter, 4: very bitter, 5: extremely bitter; A-D: bars with different uppercase letters are significantly different $(p<0.05)$. Values represent the means and standard deviations ( $\mathrm{i}=2, n_{\text {panelists }} \geq 12$ ). 

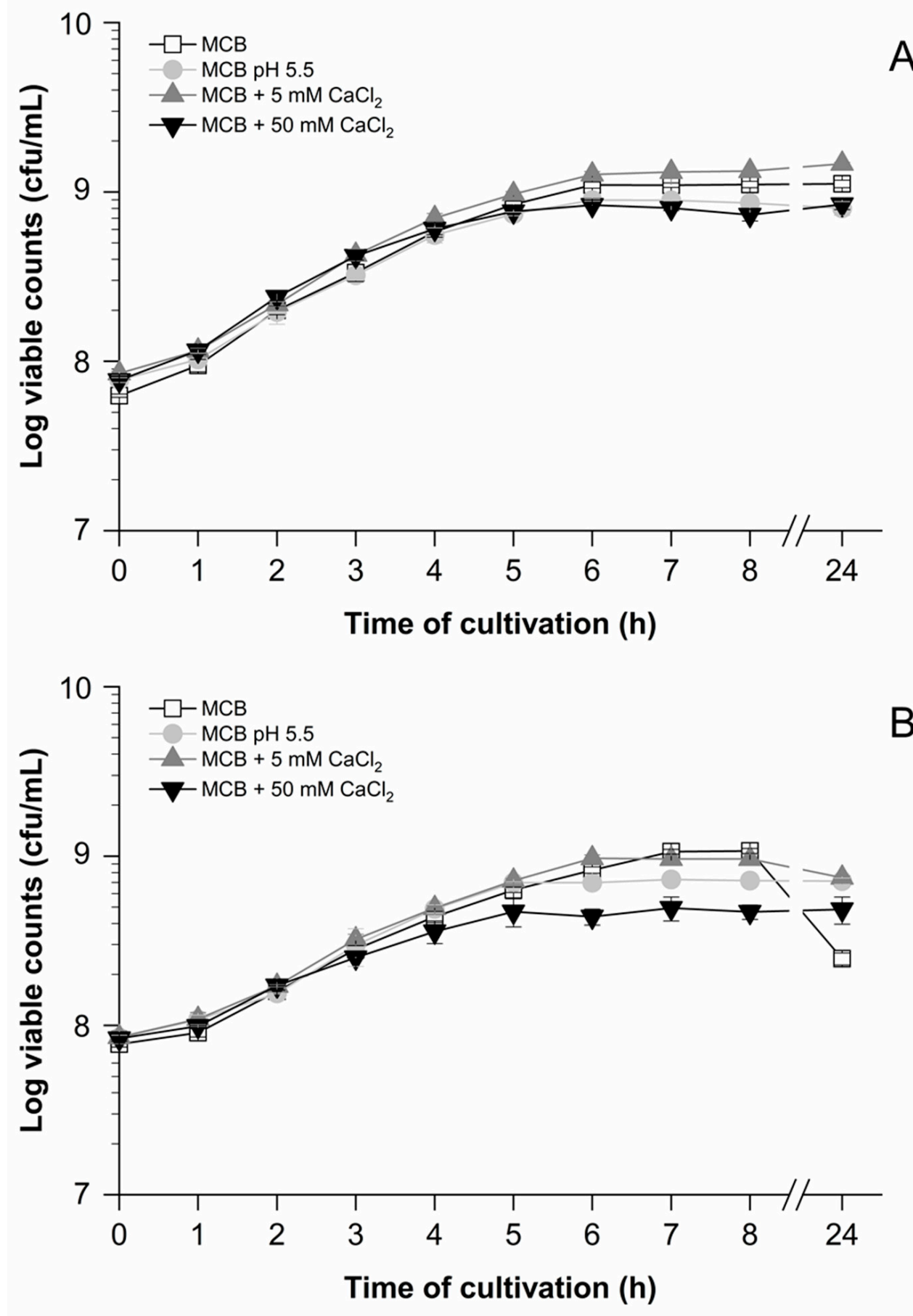

Figure 2. Semilogarithmic graph of growth curves of strains L. lactis LTH 7122 (A) and LTH 7123 (B) in different compositions of milk citrate broth (MCB). Cultivation was conducted for $24 \mathrm{~h}$ in basic MCB (pH 6.6), MCB (pH 5.5), basic MCB plus $5 \mathrm{mM}$ calcium chloride, and basic MCB plus $50 \mathrm{mM}$ calcium chloride at $30{ }^{\circ} \mathrm{C}$ without agitation. The viable counts $(\mathrm{cfu} / \mathrm{mL})$ were determined hourly. Data represent mean values and standard deviations from biological and technical duplicates. 


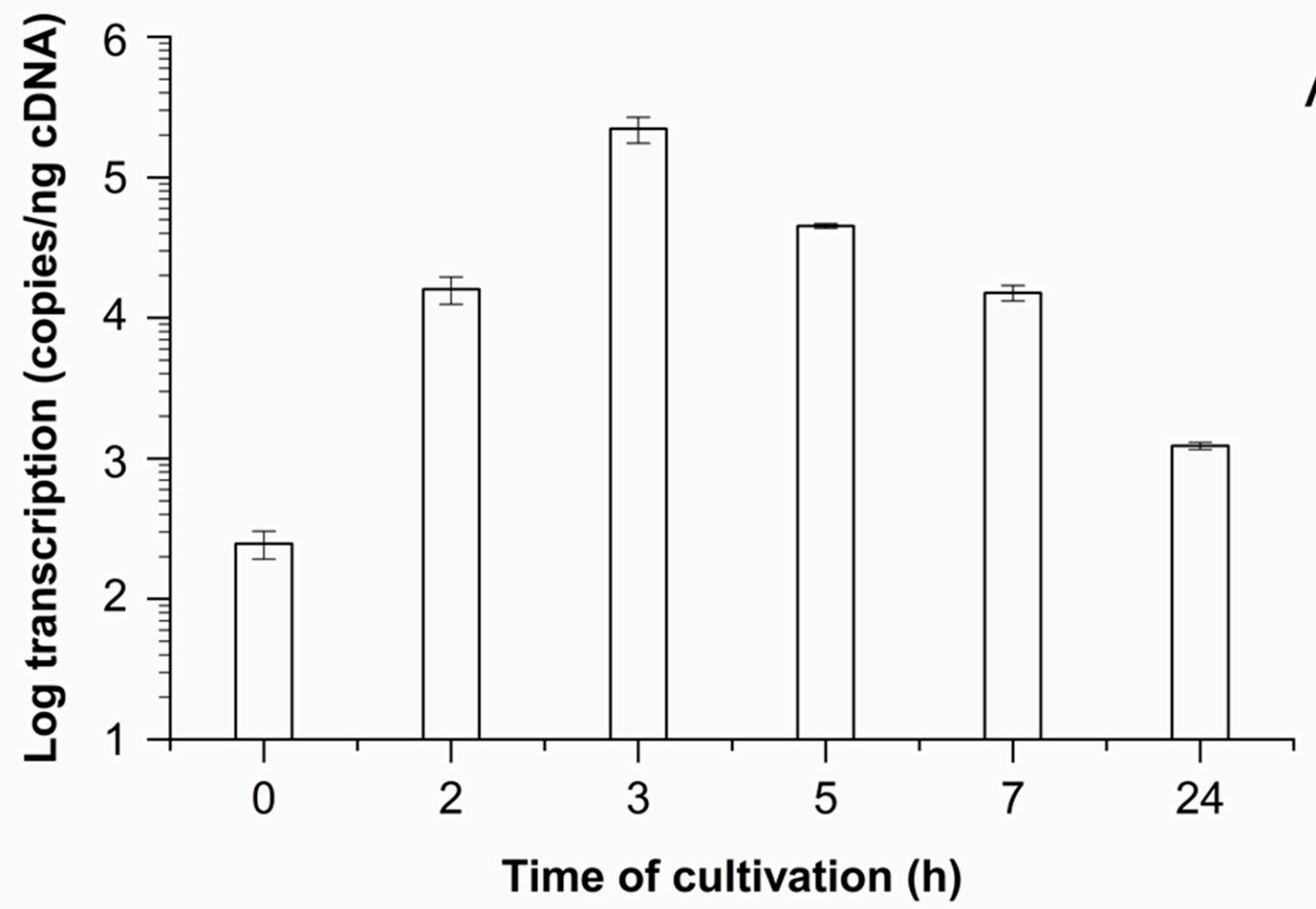

A

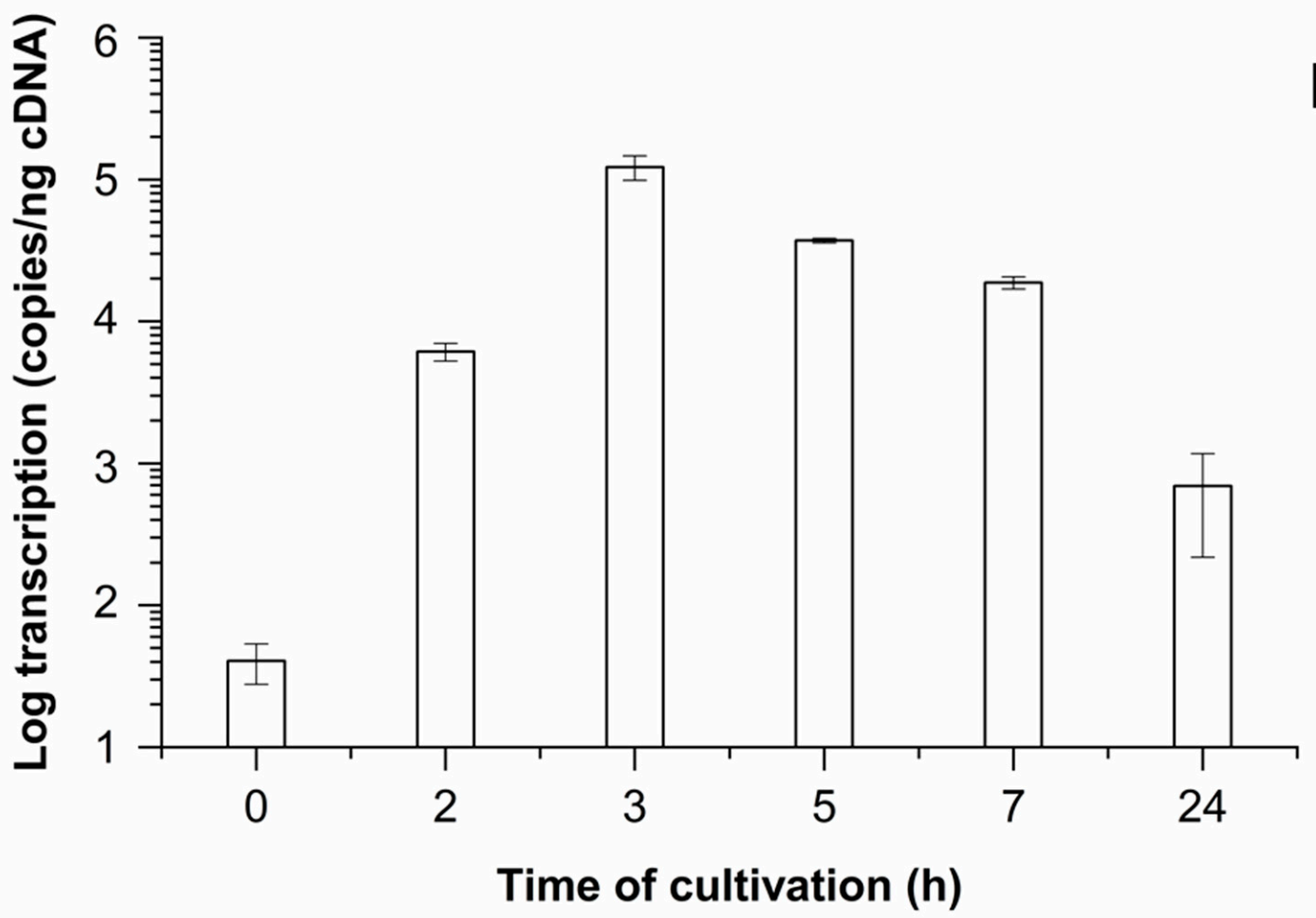

Figure 3. prtP transcription of strains L. lactis LTH 7122 (A) and LTH 7123 (B) during growth in basic MCB (pH 6.6). Cultivation was carried out for $24 \mathrm{~h}$, and samples were collected at the respective time points. The mean values and standard deviations of three biological and two technical replicates each are shown. 
3.3. Quantitative Analysis of prtP Transcription during Growth of Strains LTH 7122 and LTH 7123 in Basic MCB ( $p H$ 6.6), MCB ( $p H 5.5)$, and with Additional $5 \mathrm{mM}$ or $50 \mathrm{mM}$ Calcium Chloride

As a prerequisite for quantitative expression analysis under certain growth conditions, growth curves of strains LTH 7122 (Figure 2A) and LTH 7123 (Figure 2B) were generated in basic MCB ( $\mathrm{pH}$ 6.6), MCB (pH 5.5), and basic MCB with additional $5 \mathrm{mM}$ or $50 \mathrm{mM}$ calcium chloride. Since the supplementation of $50 \mathrm{mM}$ calcium chloride to basic MCB reduced the initial $\mathrm{pH}$ from 6.6 to 5.5, control experiments were carried out with $\mathrm{MCB}$ (pH 5.5) in order to evaluate the effect of a lowered $\mathrm{pH}$-value on growth and on prtP transcription levels (Figures 2 and 4).
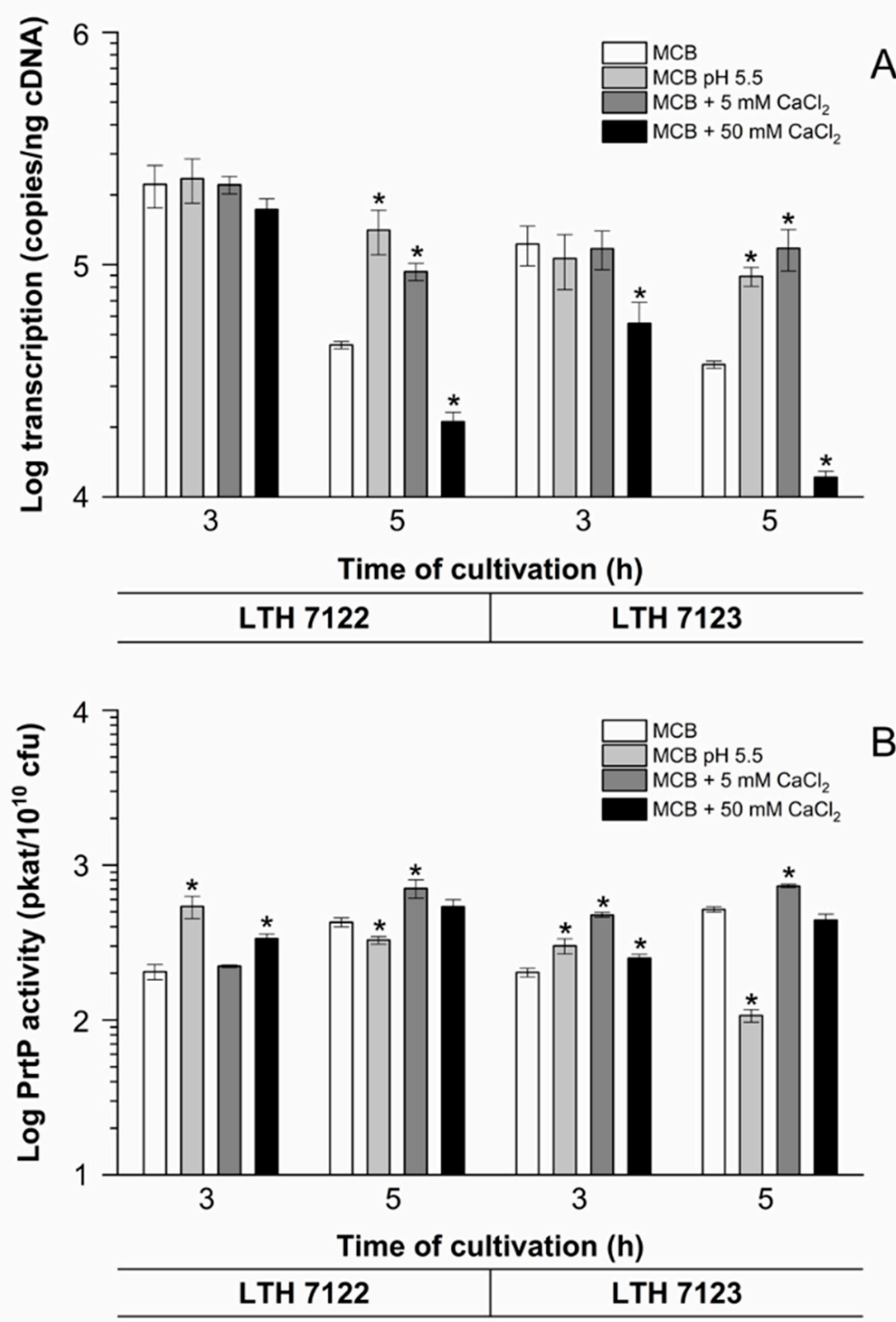

Figure 4. prtP transcription (A) and PrtP peptidase activity (B) of strains L. lactis LTH 7122 and LTH 7123 during growth in basic MCB (pH 6.6), MCB ( $\mathrm{pH} 5.5)$, and basic MCB (pH 6.6) with addition of $5 \mathrm{mM}$ or $50 \mathrm{mM}$ calcium chloride. Samples were collected after $3 \mathrm{~h}$ and $5 \mathrm{~h}$ of cultivation. The mean values and standard deviations of three biological and two technical replicates each are shown. Asterisks ${ }^{*}$ ) show statistical significance compared to the reference (basic $\left.\mathrm{MCB}, \mathrm{pH} 6.6\right)(p<0.05)$. 
In the first $5 \mathrm{~h}$ after inoculation, both strains grew well with minor differences in generation time and viable counts (Figure 2). Whereas the decrease of the $\mathrm{pH}$ value to 5.5 had only a minor growth-delaying effect on strain LTH 7122 after $5 \mathrm{~h}$ of growth, the addition of $50 \mathrm{mM}$ calcium chloride to basic MCB delayed the growth in terms of generation time and viable counts clearly in a strain-dependent manner (Figure 2A,B). However, the addition of $5 \mathrm{mM}$ calcium chloride demonstrated a slightly growth-promoting effect, which was visible throughout the growth curve with strain LTH 7122 and after $5 \mathrm{~h}$ also with LTH 7123. These data supported the idea to measure $p r t P$ transcription at time points $3 \mathrm{~h}$ and $5 \mathrm{~h}$ after inoculation.

The prtP transcription levels of strains LTH 7122 and LTH 7123 during growth in basic MCB (pH 6.6), MCB (pH 5.5), and basic MCB (pH 6.6) with addition of $5 \mathrm{mM}$ or $50 \mathrm{mM}$ calcium chloride are summarized in Figure $4 \mathrm{~A}$.

The data obtained show a high transcription level of prtP after $3 \mathrm{~h}$ of growth in basic $\mathrm{MCB}(\mathrm{pH}$ 6.6) for both strains and a lower transcription after $5 \mathrm{~h}$ of growth. For both strains, the prtP expression in $\mathrm{MCB}$ ( $\mathrm{pH}$ 5.5) was similar to that in basic MCB (pH 6.6) after $3 \mathrm{~h}$ but was increased by 212\% (LTH 7122) and 140\% (LTH 7123) after $5 \mathrm{~h}$ of growth. A decrease of prtP expression levels during growth in basic MCB ( $\mathrm{pH}$ 6.6) with additional $50 \mathrm{mM}$ calcium chloride was observed with both strains (Figure $4 \mathrm{~A}$ ). After $3 \mathrm{~h}$ and $5 \mathrm{~h}$ of growth, the prtP transcription of strains LTH 7122 and LTH 7123 was reduced.

To investigate the effect of a lower calcium chloride concentration on $\operatorname{prt} P$ transcription, $5 \mathrm{mM}$ calcium chloride was added to basic MCB ( $\mathrm{pH}$ 6.6) (Figure 4A). In contrast to the results with $50 \mathrm{mM}$ calcium chloride, prtP expression of strains LTH 7122 and LTH 7123 was affected in different ways. No effect was observed after $3 \mathrm{~h}$, but transcription was increased by $107 \%$ in strain LTH 7122 and $217 \%$ in strain LTH 7123 after 5 h of growth. These data demonstrated that a high calcium concentration of $50 \mathrm{mM}$ inhibits transcription, whereas the ten-times lower concentration promotes growth as well as prtP transcription in both tested strains.

3.4. Quantitative Analysis of PrtP Peptidase Activity during Growth of Strains LTH 7122 and LTH 7123 in Basic MCB ( $p H$ 6.6), MCB ( $p H 5.5)$, and with Additional $5 \mathrm{mM}$ or $50 \mathrm{mM}$ Calcium Chloride

The PrtP peptidase activity after $3 \mathrm{~h}$ of growth in basic MCB ( $\mathrm{pH}$ 6.6) was approximately 200 pkat $/ 10^{10} \mathrm{cfu}$ and similar for both strains (Figure 4B). Accordingly, PrtP peptidase activity increased for both strains during the late exponential growth phase. The PrtP peptidase activity increased also during growth in $\mathrm{MCB}(\mathrm{pH}$ 5.5) after $3 \mathrm{~h}$ of cultivation compared to the PrtP peptidase activity of cells grown in basic MCB ( $\mathrm{pH}$ 6.6). However, after $5 \mathrm{~h}$ of growth, the PrtP peptidase activity of both strains was lower than at time point $3 \mathrm{~h}$.

The addition of $5 \mathrm{mM} \mathrm{CaCl}_{2}$ to basic MCB ( $\mathrm{pH}$ 6.6) led also to an increase in PrtP peptidase activity. For strain LTH 7122 a longer adaption to the conditions of elevated calcium was required, as the increased PrtP peptidase activity was determined just after $5 \mathrm{~h}$ of growth. In the beginning of the exponential growth at $3 \mathrm{~h}$, this strain showed a PrtP peptidase activity similar to the PrtP peptidase activity of cells grown in basic MCB ( $\mathrm{pH}$ 6.6) after 3 h of growth (Figure 4B). Strain LTH 7123 showed an increased PrtP peptidase activity from the beginning of exponential growth.

The PrtP peptidase activity increased for both strains during the exponential growth phase in basic MCB (pH 6.6) supplemented with $50 \mathrm{mM} \mathrm{CaCl}_{2}$. The PrtP peptidase activity of strain LTH 7123 was comparable to cells grown in basic MCB (pH 6.6), whereas PrtP peptidase activity of strain LTH 7122 increased to a low extent. At the end of exponential growth, PrtP peptidase activities were similar for both strains and comparable to the PrtP peptidase activity of cells grown in MCB medium. 
3.5. Quantitative Analysis of prtP Transcription during Growth of Strain LTH 7122 in Reconstituted Casein Medium with Different Protein and Calcium Concentrations

In order to confirm the results obtained in the experiments with $\mathrm{MCB}$ and to include the influence of elevated protein concentrations, a series of experiments was conducted using reconstituted casein medium with different protein and calcium concentrations (see Section 2.6.1). With this set of experiments, we wanted to shed light on the question of why the fermentation of milk concentrates, in contrast to the fermentation of milk, leads to strongly bitter-tasting fermentation products $[5,6]$.

Strain LTH 7122 was selected for fermentation due to its strong bitterness promoting effect (see Section 3.1). Slightly calcium-reduced (SdCa-mCN) and highly calcium-reduced (HdCa-mCN) casein powder were used, and SdCa-mCN (protein: $3.4 \%(w / v)$; calcium: $28 \mathrm{mM}$ ) and HdCa-mCN casein medium (protein: 3.4\% (w/v); calcium: $15 \mathrm{mM}$ ) were reconstituted to the native protein concentration of milk (3.4\% $(w / v)$ protein). Additionally, reconstituted SdCa-mCN (protein: $8.5 \%(w / v)$; calcium: $70 \mathrm{mM}$ ) and HdCa-mCN casein concentrates (protein: $8.5 \%(w / v)$; calcium: $38 \mathrm{mM})$ with an elevated protein concentration of $8.5 \%(w / v)$ were used.

The results of the transcriptional analyses of the prtP gene in reconstituted casein medium, differing in calcium and protein concentration, are shown in Figure 5A. When comparing the approaches of the protein-rich reconstituted casein media (protein: $8.5 \%$ $(w / v))$ after $5 \mathrm{~h}$ of cultivation, it was found that calcium reduction had little effect on the transcription of $p r t P$. In contrast, when comparing the approaches with a native protein concentration of $3.4 \%(w / v)$, it was found that transcription was decreased by approximately $85 \%$ when using $\mathrm{HdCa}-\mathrm{mCN}$ medium. Interestingly, the comparison of SdCa-mCN medium with a native $(3.4 \%(w / v))$ and an elevated $(8.5 \%(w / v))$ protein concentration revealed that transcription was decreased significantly by approximately $47 \%$ under an elevated protein concentration. The comparison of HdCa-mCN medium with a native $(3.4 \%$ $(w / v))$ and an elevated $(8.5 \%(w / v))$ protein concentration showed the opposite effect: an increase of transcription by approximately $210 \%$ under an elevated protein concentration.

After $24 \mathrm{~h}$ of cultivation, transcription was found to be decreased by more than $90 \%$ in all approaches compared with the respective $5 \mathrm{~h}$ approaches.

Thus, these results for strain LTH 7122 clearly showed that when reconstituted proteinrich casein concentrates (protein: $8.5 \%(w / v)$ ) were used as the starting material for fermentation, there were no increased transcription rates of the $\mathrm{prtP}$ gene and also that a calcium reduction had little effect on transcription. Interestingly, even after $24 \mathrm{~h}$ of cultivation, there were no increased but significantly reduced transcription levels in the approaches with protein-rich concentrates compared to the respective approaches with a native protein concentration of $3.4 \%(w / v)$.

\subsection{Quantitative Analysis of PrtP Peptidase Activity during Growth of Strain LTH 7122 in Reconstituted Casein Medium with Different Protein and Calcium Concentrations}

L. lactis strain LTH 7122 was grown in media of reconstituted casein powders at two protein and calcium concentrations, respectively. The activity of PrtP was analyzed during exponential growth $(5 \mathrm{~h})$ and at the end of fermentation $(24 \mathrm{~h})$. Strain LTH 7122 was grown in reconstituted casein medium at a native protein concentration of $3.4 \%(w / v)$, which was compared to fermentation at an elevated protein concentration at $8.5 \%(w / v)$. At both protein concentrations, the calcium concentration was varied (Figure 5). 


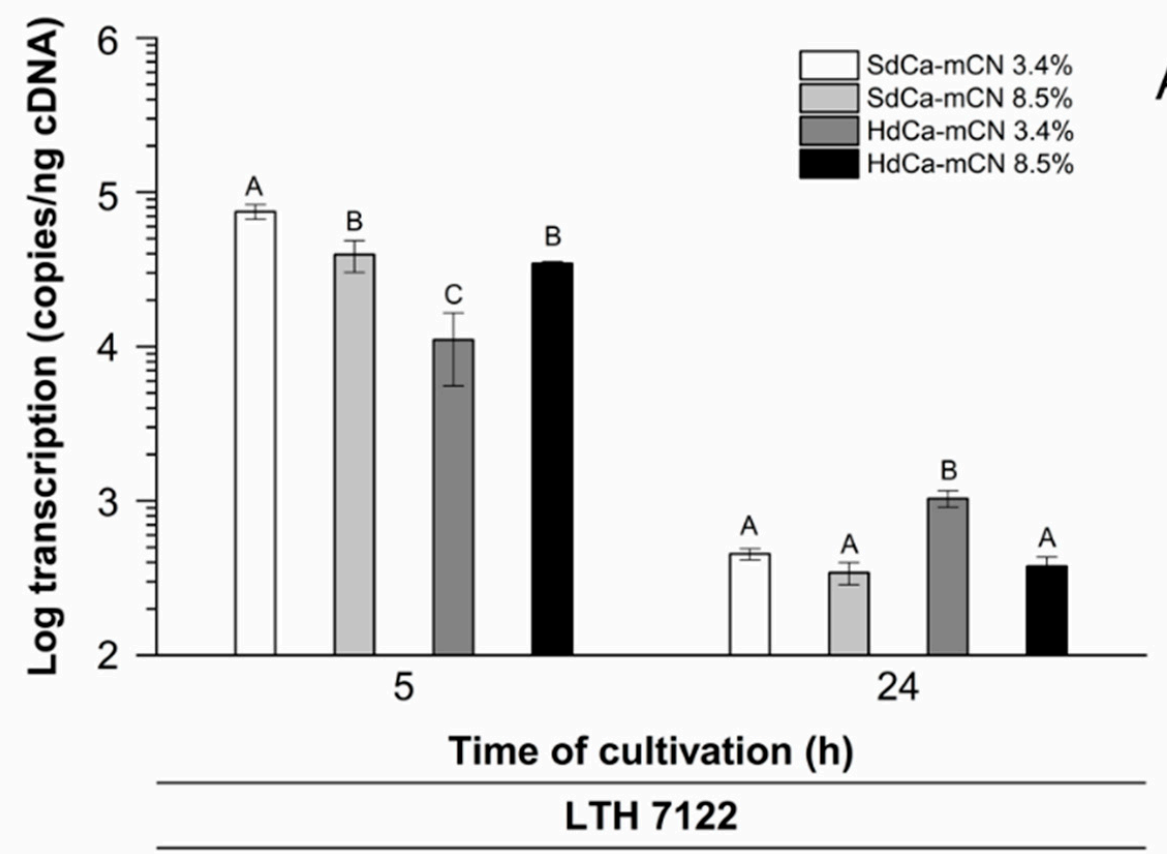

A

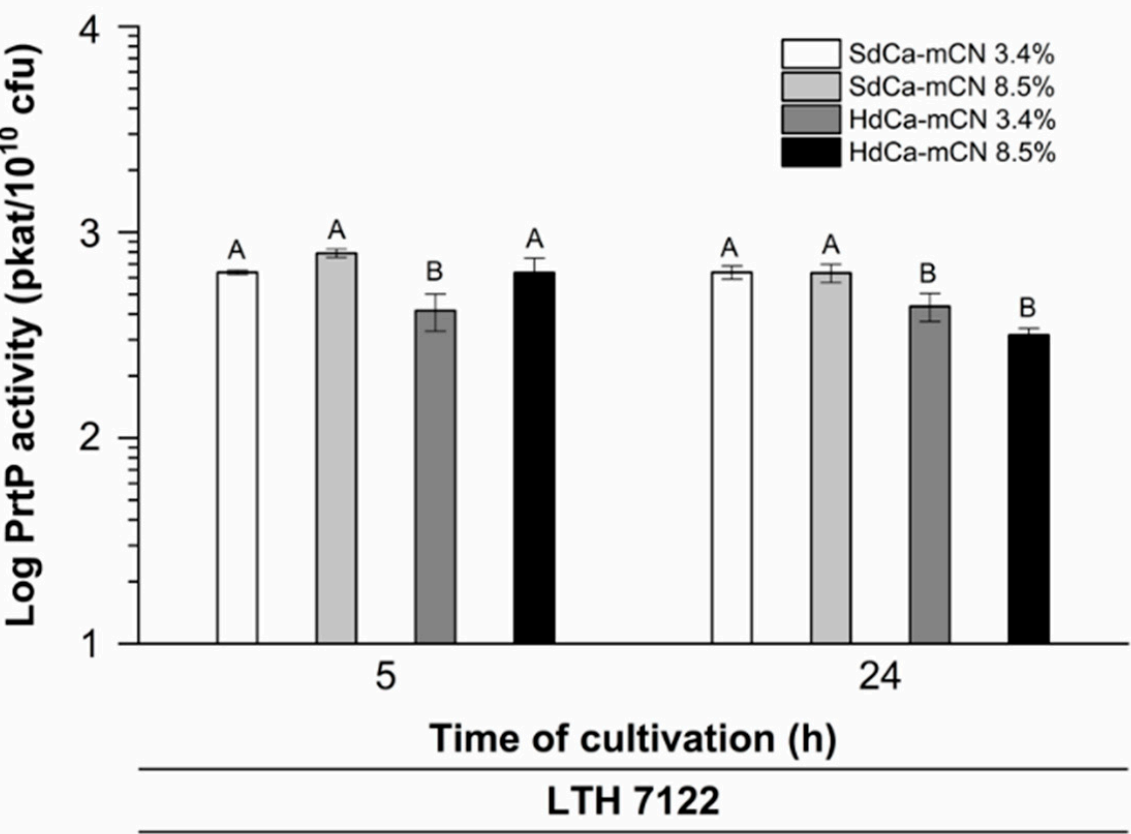

Figure 5. prtP transcription (A) and PrtP peptidase activity (B) of strain L. lactis LTH 7122 during cultivation in slightly calcium-reduced (SdCa-mCN) and highly calcium-reduced reconstituted casein medium $(\mathrm{HdCa}-\mathrm{mCN})$, each with a protein concentration of $3.4 \%(w / v)$ and $8.5 \%(w / v)$. Samples were collected after $5 \mathrm{~h}$ and $24 \mathrm{~h}$ of cultivation. The mean values and standard deviations of at least two biological replicates each are shown. A-C: bars with different uppercase letters are significantly different $(p<0.05)$. 
In SdCa-mCN medium (protein: 3.4\% (w/v); calcium: $28 \mathrm{mM}$ ), a constant PrtP activity of $637 \pm 15$ and $638 \pm 47$ pkat $/ 10^{10} \mathrm{cfu}$ was determined. In SdCa-mCN medium under elevated protein and calcium conditions (protein: $8.5 \%(w / v)$; calcium: $70 \mathrm{mM}$ ), the PrtP activity was increased to $789 \pm 38 \mathrm{pkat} / 10^{10} \mathrm{cfu}$ during the exponential growth phase of LTH 7122. After $24 \mathrm{~h}$, a similar PrtP activity as in SdCa-mCN (protein: $3.4 \%(w / v)$; calcium: $28 \mathrm{mM}$ ) was determined $\left(633 \pm 63 \mathrm{pkat} / 10^{10} \mathrm{cfu}\right)$. In $\mathrm{HdCa}-\mathrm{mCN}$ medium, the calcium concentration was reduced by $48.6 \%$ compared to native casein. To HdCa-mCN medium (protein: $3.4 \%(w / v)$; calcium: $15 \mathrm{mM}$ ), the PrtP activity reacted in the same manner as in SdCa-mCN medium and kept constant during exponential growth $(5 \mathrm{~h})$ as well as at the end of fermentation ( $24 \mathrm{~h})$. However, the level of PrtP activity was reduced $\left(416 \pm 86 \mathrm{pkat} / 10^{10} \mathrm{cfu}\right.$ and $436 \pm 68 \mathrm{pkat} / 10^{10} \mathrm{cfu}$, respectively). An increase in protein and calcium concentration of HdCa-mCN (protein: $8.5 \%(w / v)$; calcium: $38 \mathrm{mM}$ ) led to a PrtP activity comparable to SdCa-mCN (protein: $3.4 \%(w / v)$; calcium: $28 \mathrm{mM}$ ) during exponential growth $\left(636 \pm 8 \mathrm{pkat} / 10^{10} \mathrm{cfu}\right)$, while at the end of fermentation, the PrtP activity declined $\left(316 \pm 25 \mathrm{pkat} / 10^{10} \mathrm{cfu}\right)$, as seen for $\mathrm{SdCa}-\mathrm{mCN}$ medium at elevated protein conditions (protein: $8.5 \%(w / v)$; calcium: $70 \mathrm{mM})$.

3.7. Quantitative Analysis of Key Bitter Peptides Formed during Growth of Strain LTH 7122 in Reconstituted Casein Medium with Different Protein and Calcium Concentrations

As seen in the sensorial evaluation of $\mathrm{CoF}$ fresh cheese described before, strain LTH 7122 showed a capability to produce bitterness during fermentation. Therefore, samples from fermentation experiments described before were examined for their concentration of bitter peptides (Table 4). Based on the study of Sebald et al. [6], the seventeen published key bitter peptides derived from different casein fractions were used for that investigation.

Sixteen of the seventeen key peptides were found in the fermentation samples although at low concentrations, in most cases. In SdCa-mCN medium (protein: 3.4\% $(w / v)$; calcium: $28 \mathrm{mM}$ ), the concentration of peptides increased in the progress of fermentation and as well as at elevated protein and calcium conditions (protein: $8.5 \%(w / v)$; calcium: $70 \mathrm{mM}$ ). Especially the peptides VLPVPQ, MAPKHKEMPFPKYPVEPF (both derived from $\beta$-casein), and ARHPHPHLSFM (derived from $\kappa$-casein) were determined in higher concentrations. In comparison to that, in $\mathrm{HdCa}-\mathrm{mCN}$ (protein: $3.4 \%(w / v)$; calcium: $15 \mathrm{mM}$ ) the peptide concentrations were found in comparable or lower concentrations except for the peptides MAPKHKEMPFPKYPVEPF and KVLPVPQKAVPYPQ, which derived from $\beta$-casein. The increase in protein and calcium content in casein concentrate $\mathrm{HdCa}-$ $\mathrm{mCN}$ (protein: $8.5 \%(w / v)$; calcium: $38 \mathrm{mM})$ led to higher peptide concentrations than in HdCa-mCN medium (protein: $3.4 \%(w / v)$; calcium: $15 \mathrm{mM})$. Compared to SdCa-mCN medium (protein: $3.4 \%(w / v)$; calcium: $28 \mathrm{mM}$ ), most peptide concentrations were increased although the calcium concentration was at a comparable level. The highest peptide concentrations were determined for ARHPHPHLSFM in the fermentation samples. This peptide derived from $\kappa$-casein and is also stated to be a primary contribution to bitterness.

Nevertheless, the DoT-factors were $<0.1$ for the majority of the samples except for ARHPHPHLSFM, which additionally showed the highest DoT-factor of 0.7 in SdCa-mCN (protein: $8.5 \%(w / v)$; calcium: $70 \mathrm{mM}$ ). 


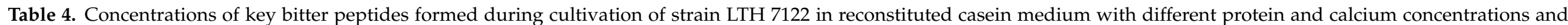
corresponding DoT factors. -: peptide concentrations too low for detection.

\begin{tabular}{|c|c|c|c|c|c|c|c|c|c|}
\hline \multirow{3}{*}{ Derived From } & \multirow{3}{*}{ Peptide Sequence } & \multicolumn{8}{|c|}{ Peptide Concentration $(\mu \mathrm{mol} / \mathrm{kg})$ (DoT-Factor $(-))$} \\
\hline & & \multicolumn{2}{|c|}{$3.4 \%(w / v)$ SdCa-mCN } & \multicolumn{2}{|c|}{$8.5 \%(w / v)$ SdCa-mCN } & \multicolumn{2}{|c|}{$3.4 \%(w / v)$ HdCa-mCN } & \multicolumn{2}{|c|}{$8.5 \%(w / v)$ HdCa-mCN } \\
\hline & & $5 \mathrm{~h}$ & $24 \mathrm{~h}$ & $5 \mathrm{~h}$ & $24 \mathrm{~h}$ & $5 \mathrm{~h}$ & $24 \mathrm{~h}$ & $5 \mathrm{~h}$ & $24 \mathrm{~h}$ \\
\hline \multirow{5}{*}{$\alpha_{\mathrm{s} 1}$-Casein } & VAPFPEVPGKE & $\begin{array}{l}0.15 \pm 0.01 \\
\quad(<0.1)\end{array}$ & $\begin{array}{l}0.58 \pm 0.01 \\
\quad(<0.1)\end{array}$ & $\begin{array}{l}0.25 \pm 0.01 \\
\quad(<0.1)\end{array}$ & $\begin{array}{l}1.36 \pm 0.10 \\
\quad(<0.1)\end{array}$ & $\begin{array}{l}0.13 \pm 0.00 \\
\quad(<0.1)\end{array}$ & $\begin{array}{l}0.50 \pm 0.01 \\
\quad(<0.1)\end{array}$ & $\begin{array}{l}0.13 \pm 0.00 \\
\quad(<0.1)\end{array}$ & $\begin{array}{c}1.78 \pm 0.02 \\
\quad(<0.1)\end{array}$ \\
\hline & VFGKEKVNEL & - & $\begin{array}{l}0.13 \pm 0.01 \\
\quad(<0.1)\end{array}$ & $\begin{array}{l}0.03 \pm 0.01 \\
\quad(<0.1)\end{array}$ & $\begin{array}{l}0.35 \pm 0.40 \\
\quad(<0.1)\end{array}$ & - & $\begin{array}{l}0.16 \pm 0.00 \\
\quad(<0.1)\end{array}$ & - & $\begin{array}{l}1.44 \pm 0.08 \\
\quad(<0.1)\end{array}$ \\
\hline & DIKQM & - & - & - & - & - & - & - & - \\
\hline & EIVPNS(PHOS)VEQK & - & - & $\begin{array}{l}0.88 \pm 0.08 \\
\quad(<0.1)\end{array}$ & $\begin{array}{l}0.83 \pm 0.20 \\
\quad(<0.1)\end{array}$ & - & - & $\begin{array}{l}0.59 \pm 0.02 \\
\quad(<0.1)\end{array}$ & $\begin{array}{l}2.30 \pm 0.30 \\
\quad(<0.1)\end{array}$ \\
\hline & IQKEDVPS & - & - & (No.) & $\begin{array}{l}0.09 \pm 0.01 \\
\quad(<0.1)\end{array}$ & - & - & (Non) & $\begin{array}{l}0.14 \pm 0.01 \\
\quad(<0.1)\end{array}$ \\
\hline \multirow{5}{*}{$\beta$-Casein } & TQTPVVVPPFLQPE & - & - & $\begin{array}{l}0.05 \pm 0.01 \\
\quad(<0.1)\end{array}$ & $\begin{array}{l}0.58 \pm 0.01 \\
\quad(<0.1)\end{array}$ & - & $\begin{array}{l}0.03 \pm 0.00 \\
\quad(<0.1)\end{array}$ & - & $\begin{array}{l}0.91 \pm 0.02 \\
\quad(<0.1)\end{array}$ \\
\hline & MAPKHKEMPFPКYPVEPF & $\begin{array}{l}0.02 \pm 0.00 \\
\quad(<0.1)\end{array}$ & $\begin{array}{l}0.36 \pm 0.04 \\
\quad(<0.1)\end{array}$ & $\begin{array}{l}0.05 \pm 0.01 \\
\quad(<0.1)\end{array}$ & $\begin{array}{l}0.87 \pm 0.10 \\
\quad(<0.1)\end{array}$ & - & $\begin{array}{l}0.61 \pm 0.01 \\
\quad(<0.1)\end{array}$ & $\begin{array}{l}0.06 \pm 0.00 \\
\quad(<0.1)\end{array}$ & $\begin{array}{l}1.33 \pm 0.18 \\
\quad(<0.1)\end{array}$ \\
\hline & LHLPLP & (no.) & $\begin{array}{l}0.51 \pm 0.10 \\
\quad(<0.1)\end{array}$ & (10.) & $\begin{array}{l}1.01 \pm 0.02 \\
\quad(<0.1)\end{array}$ & - & $\begin{array}{l}0.15 \pm 0.01 \\
\quad(<0.1)\end{array}$ & - & - \\
\hline & KVLPVPQKAVPYPQ & $\begin{array}{l}0.06 \pm 0.01 \\
\quad(<0.1)\end{array}$ & $\begin{array}{l}0.10 \pm 0.01 \\
\quad(<0.1)\end{array}$ & $\begin{array}{l}0.09 \pm 0.02 \\
\quad(<0.1)\end{array}$ & $\begin{array}{c}0.30 \pm 0.04 \\
\quad(<0.1)\end{array}$ & - & $\begin{array}{l}0.28 \pm 0.01 \\
\quad(<0.1)\end{array}$ & $\begin{array}{l}0.16 \pm 0.01 \\
\quad(<0.1)\end{array}$ & $\begin{array}{c}1.29 \pm 0.04 \\
(<0.1)\end{array}$ \\
\hline & VLPVPQ & $\begin{array}{l}0.57 \pm 0.10 \\
\quad(<0.1)\end{array}$ & $\begin{array}{l}2.79 \pm 0.40 \\
\quad(<0.1)\end{array}$ & $\begin{array}{l}1.61 \pm 0.20 \\
\quad(<0.1)\end{array}$ & $\begin{array}{l}6.82 \pm 1.10 \\
\quad(<0.1)\end{array}$ & $\begin{array}{l}0.21 \pm 0.01 \\
\quad(<0.1)\end{array}$ & $\begin{array}{l}1.14 \pm 0.04 \\
\quad(<0.1)\end{array}$ & $\begin{array}{l}0.30 \pm 0.02 \\
\quad(<0.1)\end{array}$ & $\begin{array}{c}3.38 \pm 0.12 \\
\quad(<0.1)\end{array}$ \\
\hline \multirow{5}{*}{$\kappa$-Casein } & FFSDKIAK & - & - & - & - & - & - & - & - \\
\hline & YQQPVAL & - & $\begin{array}{c}4.30 \pm 0.16 \\
(<0.1)\end{array}$ & - & $\begin{array}{c}0.08 \pm 0.02 \\
(<0.1)\end{array}$ & - & $\begin{array}{l}0.11 \pm 0.00 \\
\quad(<0.1)\end{array}$ & - & $\begin{array}{l}0.31 \pm 0.00 \\
\quad(<0.1)\end{array}$ \\
\hline & ARHPHPHLSFM & $\begin{array}{l}0.66 \pm 0.01 \\
\quad(<0.1)\end{array}$ & $\begin{array}{c}11.20 \pm 1.52 \\
(0.4)\end{array}$ & $\begin{array}{l}0.99 \pm 0.01 \\
\quad(<0.1)\end{array}$ & $\begin{array}{c}19.93 \pm 1.40 \\
(0.7)\end{array}$ & $\begin{array}{l}0.21 \pm 0.01 \\
\quad(<0.1)\end{array}$ & $\begin{array}{l}1.89 \pm 0.13 \\
\quad(<0.1)\end{array}$ & $\begin{array}{l}0.30 \pm 0.04 \\
\quad(<0.1)\end{array}$ & $\begin{array}{c}2.80 \pm 0.33 \\
(0.1)\end{array}$ \\
\hline & $\begin{array}{l}\text { AIPPKKNQDKTEIPT- } \\
\text { INTIASGEPT }\end{array}$ & - & (an & - & $\begin{array}{c}0.22 \pm 0.01 \\
(<0.1)\end{array}$ & - & - & - & - \\
\hline & INTIASGEPT & - & - & - & - & - & - & - & - \\
\hline
\end{tabular}




\section{Discussion}

In the current study, $p r t P$ transcription and PrtP peptidase activity of two $p r t P$-positive single starter strains that were isolated from a commercial starter culture were analyzed in $\mathrm{MCB}$ and reconstituted casein media with various calcium and protein concentrations. The two strains were chosen since the sensory analyses of fermented concentrated milk (containing approximately $74 \mathrm{mM}$ calcium) revealed that both strains induce a strong sensory bitterness in the fermented dairy products.

Our findings that the CoF-fresh cheese sample fermented with the prtP-negative strain LTH 7112 was significantly more bitter than the CoF-control indicates that even prtPnegative strains may be able to induce bitterness in $\mathrm{CoF}$ fresh cheese to some extent. Even the control $\mathrm{CoF}$ fresh cheese was perceived as very slightly bitter (bitterness level of 1.0), which was not completely in line with results of Poulsen and Mogensen [38], who reported that an ultrafiltration retentate, which was acidified with glucono- $\delta$-lactone, was perceived as not bitter. The slight differences between both control and reference samples show that it was difficult for the panelists to differentiate between those low bitter-tasting samples.

The growth curve analyses in different compositions of MCB medium revealed that the addition of $5 \mathrm{mM}$ calcium chloride to basic $\mathrm{MCB}$ caused a growth promoting and the addition of $50 \mathrm{mM}$ calcium chloride a growth-impairing effect on both strains LTH 7122 and LTH 7123. Since growth rates of LAB in milk are strongly dependent on casein proteolysis $[12,14,39,40]$, similar effects regarding the transcription levels and the enzymatic activity of the cell-envelope peptidase PrtP were expected. Since proteolysis by the PrtP peptidase activity leads to various casein-derived oligopeptides, among them also bitter tasting peptides $[12,13,24-26]$, an upregulation of $\operatorname{prtP}$ could also be considered as a bitterness-increasing process.

The results of the transcriptional analyses in basic MCB coincide with the previously described findings that PrtP peptidase activity is crucial for growth in milk [39] and that the expression level also depends on the growth phase and growth rate [41-43].

In the experiments using different compositions of $\mathrm{MCB}$, elevated concentrations of $\mathrm{CaCl}_{2}(50 \mathrm{mM})$ were shown to decrease prtP transcription, which is in contrast to the initial hypothesis that high levels of calcium lead to an upregulation of prtP. However, upon the addition of $5 \mathrm{mM}$ calcium chloride, higher transcription levels of prtP were observed.

In contrast to the transcriptional analyses, it could be shown that the addition of calcium to basic MCB resulted generally in a higher PrtP activity during bacterial growth. A similar behavior was already published by Exterkate [44], who stated that the PrtP peptidase activity of L. lactis ssp. cremoris strain $\mathrm{AM}_{1}$ depends on the calcium concentration of the surrounding medium. In their study, an addition of $5 \mathrm{mM}$ calcium to the growth medium increased the PrtP peptidase activity compared to cells grown on the same medium without the added calcium. It was found that the addition of $50 \mathrm{mM}$ also increased the proteolytic activity of the PrtP peptidase although to a lesser extent than $5 \mathrm{mM}$.

The cultivation experiments in reconstituted casein medium with $3.4 \%(w / v)$ and $8.5 \%(w / v)$ protein content revealed that $p r t P$ transcription was not clearly increased when strain LTH 7122 was grown in protein-rich casein concentrates. Additionally, high calcium concentrations also did not clearly increase $p r t P$ transcription. These results suggest that the previously observed increased bitterness in calcium-rich, fermented dairy products, which was also described by Schäfer et al. and Sebald et al. [5,6], cannot be explained by sheer alterations in $p r t P$ transcription due to high calcium or protein concentrations.

In contrast to the transcription levels, PrtP peptidase activity was mainly increased at elevated calcium and protein concentrations. These results are in line with the study of Exterkate [44], who observed increased activity at elevated calcium conditions. The quantification of key bitter peptides within those samples revealed higher peptide concentrations at elevated protein- and calcium concentrations. Two of those peptides (MAPKHKEMPFPKYPVEPF and ARHPHPHLSFM) are known to exhibit a low taste threshold and thus can be assumed to have a strong impact on bitterness perception [6]. Especially for the $\kappa$-casein derived peptide ARHPHPHLSFM, concentrations up to $20 \mu \mathrm{mol} / \mathrm{kg}$ were determined after 
$24 \mathrm{~h}$ of fermentation in $8.5 \%(w / v)$ protein at a calcium concentration of $70 \mathrm{mM}$. For the other investigated bitter peptides, a similar increase in concentration was observed under increased protein concentrations and furthermore with increasing calcium concentrations. Although the concentrations of the peptides alone are below the taste thresholds [6], it is possible that the combination of different bitter peptides has a synergistic effect, and the taste perception is yet bitter for the consumer. The observed strain dependency of our results is in accordance with results of Meijer et al. [42], who reported a strain-dependent regulation of lactococcal PrtP peptidase activity.

\section{Conclusions}

The sensorial evaluation revealed a perceivable bitterness in high-protein fresh cheese fermented with $\operatorname{prtP} P$-positive $L$. lactis strains, whereas $\operatorname{prtP}$-negative $L$. lactis strains did not introduce bitterness. Although the $p r t P$-gene expression was not upregulated by highly elevated calcium or protein concentrations, the PrtP peptidase activity was increased, resulting in higher concentrations of bitter peptides within the investigated casein media. Thus, the problem of bitterness in high-protein dairy products might be caused by certain L. lactis strains and their extracellular endopeptidase PrtP. A sensible selection and combination of $p r t P$-positive and -negative starter strains might be a useful tool to overcome the difficulty of bitterness in high-protein dairy products and should be investigated in future studies.

Supplementary Materials: The following are available online at https:/ /www.mdpi.com/article/10 .3390 / foods10071588/s1, Figure S1. Photos of fermented-concentrated fresh cheese (FCo) used as a reference and concentrated-fermented $(\mathrm{CoF})$ fresh cheeses manufactured by means of fermentation with L. lactis strains LTH 7112 (prtP-negative), LTH 7117 (prtP-negative), LTH 7122 (prtP-positive), LTH 7123 ( prtP-positive), and without fermentation by means of direct acidification (CoF, control) before a mechanical treatment of their gels. ${ }^{1}$ The FCo fresh cheese was already mechanically treated during manufacture; Table S1. Overview of the specific sequences and their location used for the prtP sequence alignment for determination of a conserved prtP region for primer design.

Author Contributions: Conceptualization, B.F., G.H., and J.S.; methodology, B.F., G.H., J.S., C.M., and T.S.; software, B.F., G.H., and J.S.; validation, B.F., G.H., and J.S.; formal analysis, B.F., G.H., and J.S.; investigation B.F., G.H., and J.S.; resources, L.F., J.H., and H.S.; data curation, all authors; writing—original draft preparation, B.F., G.H., and J.S.; writing—review \& editing, all authors; visualization, B.F., G.H., and J.S.; supervision, H.S., L.F., J.H., A.W., and T.S.; project administration, H.S., L.F., and J.H.; funding acquisition, H.S., L.F., and J.H. All authors have read and agreed to the published version of the manuscript.

Funding: This IGF Project of the FEI is/was supported via AiF within the program for promoting the Industrial Collective Research (IGF) of the German Ministry of Economic Affairs and Energy (BMWi), based on a resolution of the German Parliament. Project AiF 19688 N.

Institutional Review Board Statement: Not applicable.

Informed Consent Statement: Not applicable.

Data Availability Statement: Data available upon request from corresponding author.

Acknowledgments: The authors thank Christian Niebuhr (Christian Hansen Holding GmbH, Nienburg/Weser, Germany) for providing the starter culture F-DVS CC-06 and Per Dedenroth Pedersen (Sacco Srl, Cadorago, Italy) for providing the prtP-negative strains LTH 7117 and LTH 7112. We also thank Markus Kranz (University of Hohenheim, Stuttgart, Germany) for skillful technical assistance. Furthermore, the authors want to thank Iris Klaiber (Core Facility, University of Hohenheim) for the mass spectrometry analysis.

Conflicts of Interest: The authors have no conflict of interest to declare.

\section{References}

1. Chandrapala, J.; Duke, M.C.; Gray, S.R.; Zisu, B.; Weeks, M.; Palmer, M.; Vasiljevic, T. Properties of acid whey as a function of $\mathrm{pH}$ and temperature. J. Dairy Sci. 2015, 98, 4352-4363. [CrossRef] 
2. Chime, J.J.; Konrad, G.; Kleinschmidt, T.; Gorzki, L. Thermal modification of functional properties of proteins from acid whey. Milchwissenschaft 2009, 64, 400-404.

3. Konrad, G.; Gorzki, L.; Kleinschmidt, T. Ultrafiltration von Sauermolke. Dtsch. Milchwirtsch. 2009, 10, 371-372.

4. Konrad, G.; Kleinschmidt, T.; Faber, W. Ultrafiltration flux of acid whey obtained by lactic acid fermentation. Int. Dairy J. 2012, 22, 73-77. [CrossRef]

5. Schäfer, J.; Sebald, K.; Dunkel, A.; Hofmann, T.; Rosenthal, I.; Schuster, R.; Atamer, Z.; Hinrichs, J. A feasibility study on the pilot scale manufacture of fresh cheese from skim milk retentates without acid whey production: Effect of calcium content on bitterness and texture. Int. Dairy J. 2019, 93, 72-80. [CrossRef]

6. Sebald, K.; Dunkel, A.; Schäfer, J.; Hinrichs, J.; Hofmann, T. Sensoproteomics: A new approach for the identification of taste-active peptides in fermented foods. J. Agric. Food Chem. 2018, 66, 11092-11104. [CrossRef]

7. Koutina, G.; Knudsen, J.C.; Andersen, U.; Skibsted, L.H. Temperature effect on calcium and phosphorus equilibria in relation to gel formation during acidification of skim milk. Int. Dairy J. 2014, 36, 65-73. [CrossRef]

8. Mortensen, B.K. Recent developments in the utilization of milk proteins in dairy products. In Milk Proteins'84, Proceedings of the International Congress on Milk Proteins; Galesloot, T.E., Tinbergen, B.J., Eds.; Centre for Agricultural Publishing and Documentation (Pudoc): Wageningen, The Netherlands, 1984; pp. 109-119.

9. Chopin, A. Organization and regulation of genes for amino acid biosynthesis in lactic acid bacteria. FEMS Microbiol. Rev. 1993, 12, 21-37. [CrossRef]

10. Christensen, J.E.; Dudley, E.G.; Pederson, J.A.; Steele, J.L. Peptidases and amino acid catabolism in lactic acid bacteria. Antonie Van Leeuwenhoek 1999, 76, 217-246. [CrossRef]

11. Doeven, M.K.; Kok, J.; Poolman, B. Specificity and selectivity determinants of peptide transport in Lactococcus lactis and other microorganisms. Mol. Microbiol. 2005, 57, 640-649. [CrossRef]

12. Kok, J. Genetics of the proteolytic system of lactic acid bacteria. FEMS Microbiol. Rev. 1990, 87, 15-42. [CrossRef]

13. Savijoki, K.; Ingmer, H.; Varmanen, P. Proteolytic systems of lactic acid bacteria. Appl. Microbiol. Biotechnol. 2006, 71, 394-406. [CrossRef] [PubMed]

14. Smid, E.J.; Poolman, B.; Konings, W.N. Casein utilization by lactococci. Appl. Environ. Microbiol. 1991, 57, 2447-2452. [CrossRef] [PubMed]

15. Liu, M.; Bayjanov, J.R.; Renckens, B.; Nauta, A.; Siezen, R.J. The proteolytic system of lactic acid bacteria revisited: A genomic comparison. BMC Genom. 2010, 11. [CrossRef]

16. Haandrikman, A.J.; Kok, J.; Laan, H.; Soemitro, S.; Ledeboer, A.M.; Konings, W.N.; Venema, G. Identification of a gene required for maturation of an extracellular lactococcal serine proteinase. J. Bacteriol. 1989, 171, 2789-2794. [CrossRef]

17. Ainsworth, S.; Stockdale, S.; Bottacini, F.; Mahony, J.; van Sinderen, D. The Lactococcus lactis plasmidome: Much learnt, yet still lots to discover. FEMS Microbiol. Rev. 2014, 38, 1066-1088. [CrossRef]

18. Exterkate, F.A. The lactococcal cell envelope proteinases: Differences, calcium-binding effects and role in cheese ripening. Int. Dairy J. 1995, 5, 995-1018. [CrossRef]

19. Kok, J.; Hill, D.; Haandrikman, A.J.; De Reuver, M.J.B.; Laan, H.; Venema, G. Deletion analysis of the proteinase gene of Streptococcus cremoris Wg2. Appl. Environ. Microbiol. 1988, 54, 239-244. [CrossRef] [PubMed]

20. Exterkate, F.A.; Alting, A.C. Role of calcium in activity and stability of the Lactococcus lactis cell envelope proteinase. Appl. Environ. Microbiol. 1999, 65, 1390-1396. [CrossRef]

21. Laan, H.; Konings, W.N. Mechanism of proteinase release from Lactococcus lactis subsp. cremoris Wg2. Appl. Environ. Microbiol. 1989, 55, 3101-3106. [CrossRef]

22. Exterkate, F.A.; Alting, A.C.; Bruinenberg, P.G. Diversity of cell envelope proteinase specificity among strains of Lactococcus lactis and its relationship to charge characteristics of the substrate-binding region. Appl. Environ. Microbiol. 1993, 59, 3640-3647. [CrossRef]

23. Broadbent, J.R.; Strickland, M.; Weimer, B.C.; Johnson, M.E.; Steele, J.L. Peptide accumulation and bitterness in Cheddar cheese made using single-strain Lactococcus lactis starters with distinct proteinase specificities. J. Dairy Sci. 1998, 81, 327-337. [CrossRef]

24. Broadbent, J.R.; Barnes, M.; Brennand, C.; Strickland, M.; Houck, K.; Johnson, M.E.; Steele, J.L. Contribution of Lactococcus lactis cell envelope proteinase specificity to peptide accumulation and bitterness in reduced-fat cheddar cheese. Appl. Environ. Microbiol. 2002, 68, 1778-1785. [CrossRef]

25. Steele, J.; Broadbent, J.; Kok, J. Perspectives on the contribution of lactic acid bacteria to cheese flavor development. Curr. Opin. Biotechnol. 2013, 24, 135-141. [CrossRef]

26. Tsakalidou, E.; Anastasiou, R.; Vandenberghe, I.; van Beeumen, J.; Kalantzopoulos, G. Cell-wall-bound proteinase of Lactobacillus delbrueckii subsp. lactis ACA-DC 178: Characterization and specificity for $\beta$-casein. Appl. Environ. Microbiol. 1999, 65, 2035-2040. [CrossRef] [PubMed]

27. Kojic, M.; Fira, D.; Banina, A.; Topisirovic, L. Characterization of the cell wall-bound proteinase of Lactobacillus casei HN14. Appl. Environ. Microbiol. 1991, 57, 1753-1757. [CrossRef]

28. Sambrook, J.F.; Russell, D.W. Molecular Cloning: A Laboratory Manual, 3rd ed.; Cold Spring Harbor Laboratory Press: Cold Spring Harbor, NY, USA, 2001; ISBN 978-087969577-4.

29. Schäfer, J.; Hinrichs, J.; Kohlus, R.; Huppertz, T.; Atamer, Z. Pilot scale processing and characterisation of calcium-reduced micellar casein concentrate powders. Int. Dairy J. 2021, 113, 104888. [CrossRef] 
30. Schäfer, J.; Läufle, I.; Schmidt, C.; Atamer, Z.; Nöbel, S.; Sonne, A.; Kohlus, R.; Hinrichs, J. The sol-gel transition temperature of skim milk concentrated by microfiltration as affected by $\mathrm{pH}$ and protein content. Int. J. Dairy Technol. 2018, 71, 585-592. [CrossRef]

31. DIN. Sensory Analysis-Methodology-Method of Investigating Sensitivity of Taste (ISO 3972:2011 + Cor. 1:2012). DIN ISO 3972:2013-12 (2013, December 1); Beuth Verlag GmbH: Berlin, Germany; Deutsches Institut für Normung: Berlin, Germany, 2013.

32. de Saldamando, L.; Delgado, J.; Herencia, P.; Giménez, A.; Ares, G. Polarized sensory positioning: Do conclusions depend on the poles? Food Qual. Prefer. 2013, 29, 25-32. [CrossRef]

33. Meinlschmidt, P.; Sussmann, D.; Schweiggert-Weisz, U.; Eisner, P. Enzymatic treatment of soy protein isolates: Effects on the potential allergenicity, technofunctionality, and sensory properties. Food Sci. Nutr. 2016, 4, 11-23. [CrossRef]

34. Anderson, D.G.; McKay, L.L. Simple and rapid method for isolating large plasmid DNA from lactic streptococci. Appl. Environ. Microbiol. 1983, 46, 549-552. [CrossRef]

35. Bustin, S.A.; Benes, V.; Garson, J.A.; Hellemans, J.; Huggett, J.; Kubista, M.; Mueller, R.; Nolan, T.; Pfaffl, M.W.; Shipley, G.L.; et al. The MIQE Guidelines: Minimum information for publication of quantitative real-time PCR experiments. Clin. Chem. 2009, 55, 611-622. [CrossRef]

36. Hebert, E.M.; Mamone, G.; Picariello, G.; Raya, R.R.; Savoy, G.; Ferranti, P.; Addeo, F. Characterization of the pattern of $\alpha_{\mathrm{s} 1}$ - and $\beta$-casein breakdown and release of a bioactive peptide by a cell envelope proteinase from Lactobacillus delbrueckii subsp. lactis CRL 581. Appl. Environ. Microbiol. 2008, 74, 3682-3689. [CrossRef]

37. Kok, J.; Venema, G. Genetics of proteinases of lactic acid bacteria. Biochimie 1988, 70, 475-488. [CrossRef]

38. Poulsen, P.R.; Mogensen, G. Consistency and Flavour Development in Ymer made from Ultrafiltrated Milk (No. 245); The Danish Government Research Institute for Dairy Industry: Hilleroed, Denmark, 1981.

39. Gitton, C.; Meyrand, M.; Wang, J.; Caron, C.; Trubuil, A.; Guillot, A.; Mistou, M.-Y. Proteomic signature of Lactococcus lactis NCDO763 cultivated in milk. Appl. Environ. Microbiol. 2005, 71, 7152-7163. [CrossRef]

40. Kunji, E.R.S.; Mierau, I.; Hagting, A.; Poolman, B.; Konings, W.N. The proteolytic systems of lactic acid bacteria. Antonie Van Leeuwenhoek 1996, 70, 187-221. [CrossRef]

41. Marugg, J.D.; Meijer, W.; van Kranenburg, R.; Laverman, P.; Bruinenberg, P.G.; de Vos, W.M. Medium-dependent regulation of proteinase gene expression in Lactococcus lactis: Control of transcription initiation by specific dipeptides. J. Bacteriol. 1995, 177, 2982-2989. [CrossRef]

42. Meijer, W.; Marugg, J.D.; Hugenholtz, J. Regulation of proteolytic enzyme activity in Lactococcus lactis. Appl. Environ. Microbiol. 1996, 62, 156-161. [CrossRef]

43. Dressaire, C.; Redon, E.; Milhem, H.; Besse, P.; Loubière, P.; Cocaign-Bousquet, M. Growth rate regulated genes and their wide involvement in the Lactococcus lactis stress responses. BMC Genom. 2008, 9. [CrossRef] [PubMed]

44. Exterkate, F.A. Accumulation of proteinase in the cell wall of Streptococcus cremoris strain AM1 and regulation of its production. Arch. Microbiol. 1979, 120, 247-254. [CrossRef] 